\title{
Articles
}

\section{The Development of German Corporate Law Until 1990: An Historical Reappraisal}

\author{
By Peter Muchlinski*
}

\section{A. Introduction}

The development of modern corporate law can be located in four "origin" legal systems: France, England, Germany and the United States (specifically in leading State Jurisdictions such as New York, New Jersey and Delaware). These systems are often segregated between an Anglo-American "outsider" system of corporate law and governance and the Continental "insider" system. ${ }^{1}$ This has its political economy parallel in the "Varieties of Capitalism" literature, which separates the major capitalist economies into "Liberal Market Economies", such as the UK and the USA, and "Co-ordinated Market Economies", such as Germany. ${ }^{2}$ These distinctions concentrate, in particular, on whether the system of corporate finance is based on open stock markets and widely dispersed "outsider" shareholding, as in the Anglo-American model, or on finance carried out by "insider"

\footnotetext{
.* Peter Muchlinski is a Professor at The School of Law, SOAS, University of London. Email: pm.29@soas.ac.uk. This paper is part of a wider project on the globalization of corporate law undertaken by the author in conjunction with his colleagues at SOAS - Nick Foster, Sanzhu Zhu and Scott Newton - as represented by our joint LLM/MA course International and Comparative Corporate Law. I would like to acknowledge the support of Professor GralfPeter Calliess, the Centre for Transnational Studies and the Faculty of Law at the University of Bremen, where I was a Visiting Professor in February-March 2012, in allowing me to use their resources while undertaking the research for this paper. Thanks to Stephan von Harder for helping me with the logistical aspects of this research while in Bremen, and for his comments on an earlier draft, and to Nick Foster for his valuable comments. Also I acknowledge my debt of gratitude to my German language teachers in the 1970s at the John Fisher School: Purley, Surrey, the late Father J.M.Kensington and Mr. John Rizkalla, without whose excellent teaching this paper would not have been possible!
}

${ }^{1}$ See also Alan Dignam \& Michael Galanis, The Globalization of Corporate Governance 43-45 (2010); Henry Hansmann \& Reiner Kraakman, The End of History of Corporate Law, in CONVERGENCE AND PERSISTENCE IN CORPORATE GovernANCE 33 (Jeffrey Gordon \& Mark Roe eds., 2004), also published in 89 GEORGETOWN UNIV. L.R. 439 (2001).

${ }^{2}$ See Varieties of Capitalism: The Institutional Foundations of Comparative Advantage (Peter Hall \& David Soskice eds., 2001). For a critical appraisal of this approach, see Gregory Jackson \& Richard Deeg, From Comparing Capitalisms to the Politics of Institutional Change, 15(4) REV. OF INT'L POL. ECON. 680 (2008). 
universal investment banks with places on the supervisory organs of corporations as is often claimed to be the case for the German system. ${ }^{3}$

In more recent times Anglo-American corporate law has been seen as an expression of economic liberalism, focused on the maximization of shareholder value, given its emphasis on shareholder protection in response to the management agency problem. ${ }^{4}$ By contrast, Continental jurisdictions are said to focus more on stakeholder value and so have been less successful in adapting to the new liberal global order, leading to a more recent apparent convergence with the Anglo-American model. ${ }^{5}$ Such crude classifications along 'legal family' lines have been criticized on the basis that there is little correlation between the type of legal system, the nature of its corporate law system and levels of investor protection. ${ }^{6}$ Nor is finance through stock markets and by universal investment banks a set of alternatives that indelibly control the nature of corporate law and governance. As will be shown below, in the German case, both systems have run in parallel, except towards the end of the Nazi period and the revival of stock markets after World War II, and their impact on corporate law is far more difficult to determine than the simple dichotomy of "outsider/insider" would suggest.

\footnotetext{
${ }^{3}$ In France, the role of the State as financier is emphasised. See also DIGNAM \& GALANIS, supra note 1, at 46-48;
} Hansmann \& Kraakman, supra note 1.

\footnotetext{
${ }^{4}$ For the proposition that the common law countries are more suited to the development of financial markets because they offer, on average, better creditor rights, shareholder rights, and private property rights than countries following a civil law tradition, see Rafael La Porta, Florencio Lopez de Silanes, Adrei Shleifer \& Robert Vishny, Legal Determinants of External Finance, LII J. OF FIN. 1131 (1997); Rafael La Porta, Florencio Lopez de Silanes, Adrei Shleifer \& Robert Vishny, Law and Finance, 106 J. OF POL. ECON. 1113 (1998); Thorsten Beck, Asli Demirgüç-Kunt \& Ross Levine, Law and Finance: Why Does Legal Origin Matter?, (National Bureau of Economic Research Working Paper No. 9379, 2002), available at: http://www.nber.org/papers/w9379 (last accessed: 1 February 2013).
}

\footnotetext{
${ }^{5}$ See La Porta et. al., supra note 4; Hansmann \& Kraakman, supra note 1; see also DIGNAM \& GALANIS, supra note 1, Ch. 8, discussing how contemporary German corporate law is possibly converging towards the "outsider" approach.

${ }^{6}$ See Katerina Pistor, Yoram Keinan, Jan Kleinheisterkramp \& Mark West, The Evolution of Corporate Law: A CrossCountry Comparison, 23 U. PA. J. INT'L. ECON. L. 791 (2002). For a critique of the 'legal families' approach of La Porta, see Mathias Siems, Legal Origins: Reconciling Law \& Finance and Comparative Law, 52 MCGILL L. J. 55 (2007). For a critique specifically dealing with Germany, and rejecting the idea that Germany offers weaker protection, see Udo Braendle, Shareholder Protection in the USA and Germany - On the Fallacy of LLSV (German Working Papers in Law and Economics Paper No. 18, 2006), available at: http://www.bepress.com/gwp/default/vol2006/iss1/art18/ (last accessed: 1 February 2013).
} 
It is the purpose of this paper to re-appraise our historical understanding of corporate law in Germany. This is required, in part, because very little has been written in English in recent years on this issue. ${ }^{7}$ The history of German corporate law lives mainly in the German language. Given the pre-eminence of Germany as a major European power, as a formative influence on the development of EU corporate law and, in historical terms, as a major contributor to the development of Western legal scholarship, ${ }^{8}$ it behooves AngloAmerican scholars to become better acquainted with this field. Indeed, the global spread of corporate law, and the rise of multinational enterprises operating in numerous local corporate law systems, has transformed its study from a local, jurisdiction-based subject to a comparative subject, where knowledge of other corporate law systems is essential to a proper understanding of the nature of contemporary corporate governance and regulation.

The subject is faced with difficulties arising from the lack of a well developed comparative, historical and interdisciplinary perspective. ${ }^{9}$ Most English language scholarship on German corporate law focuses on contemporary law and pays scant attention to German economic and social history, no doubt because that is not the mission of these works. ${ }^{10}$ As a result, our view of German corporate law is missing a sense of its complex origins and evolution, which can lead to inaccurate stereotyping of a kind that allows for crude generalizations such as those found in the 'legal family' debate on corporate law. ${ }^{11}$ Indeed German

${ }^{7}$ For a detailed analysis, see AdALBERT BE ALA LeVY, PrIVATE Corporations AND their Control, Vol. I, Chapter I, sections 12, 15, 21 and 23 (1950); for a recent, very brief, summary, see DIGNAM \& GALANIS, supra note 1, at 263-267.

${ }^{8}$ On which, see Ugo Mattei, Why the Wind Changed: Intellectual Leadership in Western Law, 42 AM. J. CoMP. L. 195 (1994); Ron Harris, The Transplantation of Legal Discourse on Corporate Personality Theories: From German Codification to British Political Pluralism and American Big Business, 63 WASH. \& LeE L. ReV. 1422 (2006); KONRAD ZWEIGERT \& HEIN KOTZ, AN INTRODUCTION TO COMPARATIVE LAW 154-156 (1998).

${ }^{9}$ On the problems of the history of corporate governance, and the dangers of crude, a-historical, classifications, see Gary Herrigel, Guest Editor's Introduction: A New Wave in the History of Corporate Governance, 8(3) ENTERPRISE AND SOC. 475 (2007); and Corporate Governance, in THE OXFORD HANDBOOK OF BUSINESS HISTORY 470 (Geoffrey Jones \& Jonathan Zeitlin eds., 2009). There is also a wider problem in the apparent assumption of similarity, if not sameness, in the law and its underpinnings: see Nicholas Foster, Company Law Theory in Comparative Perspective: England and France, 48 AMER. J. OF COM. L. 573 (2000).

${ }^{10}$ See e.g., Mads Andenas \& Frank Wooldridge, European Comparative Corporate laW (2009); AndREAS CAHn \&

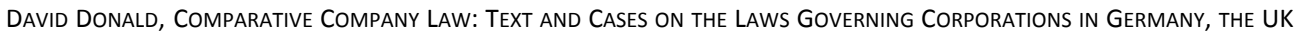
and the USA (2010); Jean Du Plessis, Bernhard Grossfeld, Claus luttermann, ingo Saenger, Otto Sandrock \& MATthias CASPER, German Corporate GovernanCE In AN INTERNATIONAL ANd EUROPEAN CONTEXT $\left(2^{\text {nd }}\right.$ ed., 2012$)$.

\footnotetext{
${ }^{11}$ This can be contrasted with the existing interdisciplinary literature on the historical development of English company law; see e.g., RON HARRIS, INDUSTRIALISING ENGLISH LAW: ENTREPRENEURSHIP AND BUSINESS ORGANISATION $1720-$
} 
corporate law has been used as an illustration of the 'otherness' of German industrial and corporate governance in ways which the findings of this paper seek to question. As will be shown, there is far more historical similarity between the development of the German corporate law system and other systems, including its Anglo-American counterpart, than the crude dichotomies mentioned above would suggest.

It is important to see how the formation of corporate law in Germany in the $19^{\text {th }}$ century is a part of a larger European exercise in legal, political, social and economic thought. This was a process of cross-national thinking, one in which comparative law methodology was central and one in which the influence of economic liberalism was on the rise. ${ }^{12}$ It is only in the first part of the $20^{\text {th }}$ century, in response to the needs of war capitalism, economic and political crises and to the Nazi seizure of power in 1933 (Machtergreifung), that German practice deviates significantly from other capitalist systems to create a divergent corporate law system. The post World War II reconstruction of German corporate law develops again in a more internationalised context as a result of the Allied Occupation, the revitalisation of liberal ideas and the desire of West Germany to re-integrate into the Western capitalist system, though by then certain elements of German corporate law, especially the two-tier board structure and its relationship with co-determination, made convergent change difficult. The German Democratic Republic is outside this narrative from 1945 to 1990 having become part of the Eastern Bloc and having adopted the Soviet system of industrial and legal organisation. It returns to the narrative in 1990, the time of German Reunification and the end point of the present analysis.

This paper is divided into chronological sections. The first section will briefly introduce the common European origins of German ideas on corporate law and will describe the first forms of corporate law in Germany up to the time of the adoption of the first all German Corporation Law (Aktienrecht) of 1870. The second section, the key section, will cover the emergence of modern German corporate law from the 1870 Law to the 1896 Stock Market Law (Börsengesetz) and the codification of German commercial and corporate law in the Commercial Code of 1897 (Handelsgesetzbuch, HGB). The third section will cover the

1844 (2000); Rob McQueen, A SOCIAL HIStory of Company LAW: GREAT BRITAIN AND tHe Australian Colonies 1854-1920 (2009). One interdisciplinary work in German covers the period 1945-1990, but it is not centred on corporate law

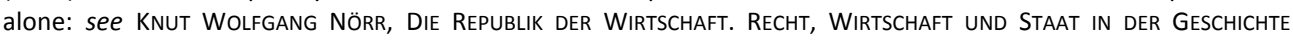
WestdeutsChlands. TeIL 1 Von der Besatzungszeit bis zUR Groben Koalition (The republic of the economy; the legal and economic state in West Germany: Part 1, 2007); KNUT Wolfgang NÖRR, DIE REPUBLIK DER WIRTSCHAFT. RECHT,

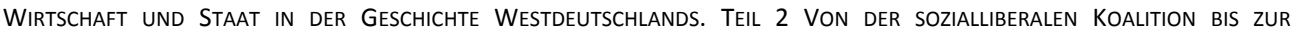
WIEDERVEREINIGUNG (The republic of the economy; the legal and economic state in West Germany: Part 2, 2007).

${ }^{12}$ See further, Helmut CoIng, Europaisches Privatrecht BANd II, 19. JAhrhundert 145-147 (European Private Law, Volume II: 19th Century, 1989); BerNHARD GROSSFELD, AKTIENGESELLSCHAFT, UNTERNEHMENSKONZENTRATION UND KLEINAKTIONÄR 132 (Corporation, Corporate Concerntration and Minority Shareholders, 1968). 
developments from 1897 up to 1945 that shift German corporate law away from a liberal capitalist model. The fourth section will cover post-1945 reconstruction, centering on the 1965 Stock Corporations Law (Aktiengesetz), the development of the co-determination system of worker participation in corporate governance and the legal impact of Reunification on East German enterprises. Finally, by way of conclusion, the challenge of globalization to the model of German corporate law will be discussed in the light of historical knowledge and its impact on comparative corporate law.

\section{B. The Foundations of German Corporate Law}

Germany has only been a unified State since $1870 .{ }^{13}$ Accordingly, prior to calls for a harmonization and codification of German laws as a means of paving the way towards German Unification, ${ }^{14}$ only particular practices and local laws can be found. German scholars have traditionally discussed the development of German corporate law by focusing on the French Code de Commerce of 1807, which is identified as the first true general corporate law, allowing for incorporation by way of a more normative and permissive system of concession by the state and with limited liability. ${ }^{15}$ The historical account concentrates on the use of the French and other comparative law precedents as the basis for the first German corporate laws of the early to mid $19^{\text {th }}$ century. ${ }^{16}$

Prior to the $19^{\text {th }}$ century, in the medieval and early modern period, German traders relied on forms of business association that evolved out of Roman precedents, such as the

\footnotetext{
${ }^{13}$ In 1866, the year when Bismarck embarked on the first stage of German unification after the defeat of Austria by Prussia, there were 38 German States: see DAVID THOMSON, EUROPE SINCE NAPOLEON 307-320 (rev. ed., 1966).
}

\footnotetext{
${ }^{14}$ On which, see further HANS SCHLOSSER, GRUndzUge DER NEUREN PRIVATRACHTSGESCHICHTE (Outline of the recent history of private law, 9th ed., 2001), in particular, Chapter 7, Die Kodifikation des Privatrechts in Deutschland (the codification of private law in Germany); see also ZWEIGERT \& KOTZ, supra note 8, at 141-154.
}

\footnotetext{
${ }^{15}$ The classic exposition of this approach is the influential work by KARL LEHMANN, DIE GESCHICHTLICHE ENTWIKLUNG DES AKTIENRECHTS BIS ZUM CODE DE COMMERCE (he Historical Development of Corporate Law up to the Code de Commerce, 1895).
}

\footnotetext{
${ }^{16}$ See e.g., KARL LehmanN, DAS ReCHT DeR AKTIEngeSEllsChaften BAND I 75-82 (The law of joint stock corporations, 1898). Norbert Reich also identifies the origins of German corporate law as beginning after the adoption of the Code de Commerce and its reception into various German State laws: Norbert Reich, Die Entwicklung des Deutschen Aktienrechts im Neunzehnten Jahrhundert (The development of the German Stock Corporation Law in the Nineteenth Century), IUS Commune II (1969), available at: http://data.rg.mpg.de/iuscommune/ic02 reich.pdf (last accessed: 1 February 2013). See also CoING, supra note 12, at 99.
} 
societas and commenda, ${ }^{17}$ and which were essentially personal in the nature of their obligations. ${ }^{18}$ In Germany the commenda was known as the "Sendegesellschaft" and it is from these roots that the "Offene Handelsgesellschaft" developed with its participants holding joint and several liability (Gesamthand). ${ }^{19}$ Family partnerships were also used, creating major trading houses such as those of Fugger, Welser and Imhoff, on the basis of renewable short-term contracts. ${ }^{20}$ Also of significance were the early shipping partnerships or "Reedereien" some of which lasted into the $19^{\text {th }}$ century. ${ }^{21}$

The first German corporate entities appear around the end of the $15^{\text {th }}$ century in the mining and metals industry (Gewerkschaften), characterized by capital divided into shares and the differentiation of company assets from those of the shareholders. ${ }^{22}$ In the $17^{\text {th }}$ century, the Netherlands, England and France pioneered the chartered trading companies, based on their own unique legal instrument, the charter or Octroi, which was granted by the state covering the public law and private law aspects of the company's operations. ${ }^{23}$

\footnotetext{
${ }^{17}$ Levy defines the societas as an association in which, "all the parties share the risks both as capitalists and as traders" while the commenda is an association in which, "one party alone undertakes the management and bears the commercial risk": LEVY, supra note 7, at 3. Levy attributes the rise of the medieval commenda to Italy where one party the tractator undertook the management of the venture, the purchase, transport and sale of the goods and was responsible to creditors, while the other partner, the commendator, provided the capital but undertook no further obligations or liability: LEVy, supra note 7, at 8. See also, LEHMANN, DAS RECHT DER AKTIENGESELLSCHAFTEN, supra note 16 , at $26-28$.
}

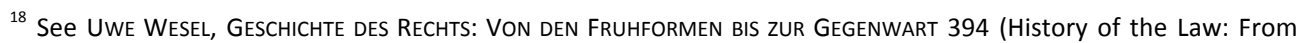
Early Forms to the Present, 3rd ed., 2006), who writes that in the years between the Middle Ages and the French Revolution business associations were dominated by "Personengesellchaften des Mittelalters." See also LEHMANN, DAS RECHT DER AKTIENGESELLSCHAFTEN, supra note 16 , at 20-21.

${ }^{19}$ WESEL, supra note 18 , at 336; LEVY, supra note 7 , at 9.

${ }^{20}$ LEVY, supra note 7, at 11. Another example is the Ravensburg Company, which lasted from 1380 to 1530 on the basis of renewable contracts: LEVY, supra note 7; WESEL, supra note 18 , at 336.

${ }^{21}$ LehmanN, DAS RECHT DER AKTIENGESELLSChAFTEN, supra note 16, at 28-29, discussing the Mediterranean origins of this type of business association; LEVY, supra note 7, at 97.

${ }^{22}$ LEVY, supra note 7, at 11-12.

${ }^{23}$ GrosSFELD, supra note 12 , at 115-116; LEVY, supra note 7, at 17-30; and generally, see STEPHEN BROWN, MERCHANT KINGS: WHEN COMPANIES RULED THE WORLD 1600-1900 (2010). 
Given the destruction wrought by the Reformation and the Thirty Years War, and the absence of major German overseas colonies, there were few enduring German chartered trading companies. ${ }^{24}$ The most significant were the Brandenburg-African Company established in 1662 and the later Prussian Königliche Seehandlung established by the Royal Patent of Frederick the Great in $1772 .{ }^{25}$

Prior to the later $19^{\text {th }}$ century, the system of state incorporation - the Concession System (Konzessionssystem) - dominated the laws of German States. ${ }^{26}$ It was justified by the need for the state to control the corporate form in the interests of protecting small shareholders and the wider public interest to control private economic and market power that could lead to monopolization. ${ }^{27}$ The Prussian State in particular adhered to this system. ${ }^{28}$ Nonetheless, the pressure to change towards a system of free incorporation became progressively irresistible, even in Prussia. In common with other industrializing nations, Germany faced the question of how to raise and regulate large capital sums needed for major industrial and infrastructure projects. ${ }^{29}$ Whether this could be done under the old system of corporate charters was open to debate. ${ }^{30}$

\footnotetext{
${ }^{24}$ LeVY, supra note 7, at 95-96; LeHMANN, DAS RECHT DER AKTIENGESELLSCHAFTEN, supra note 16, at 75.

${ }^{25}$ For a comparison of the Seehandel with the Dutch and English East India Companies, see Wilhelm Hartung, Geschichte und Rechtsstellung der Compagnie in Europa Eine Untersuchung am Beispiel der englischen East-India Company, der niederliindischen Vereenigten Oostindischen Compagnie und der preuBischen Seehandlung (History and Legal Status of the Company in Europe: A study of the English East India Company the Dutch United East India Company and the Prussian Seehandlung, 2000). Copy on file with author.
}

\footnotetext{
${ }^{26}$ According to Coing, the State grant of incorporation was a general principle of law recognised by all European systems and was at the heart of the French Code de Commerce. See Helmut Coing, Rechtsvergleichung als Grundlage von Gesetzgebung im 19 Jahrhundert (Law as the Basis of Legislation in the 19th Century), IUS COMMUNE VII, 168 (1978), available at: http://data.rg.mpg.de/iuscommune/ic07 coing.pdf (last accessed: 1 February 2013)

${ }^{27}$ GROSSFELD, supra note 12 , at 117.

${ }^{28}$ LEVY, supra note 7, at 97 . For the difficulties associated with this system in Prussia, see Reich, supra note 16, at 246- 247. On unease over corporations in Prussia, see GrosSFELD, supra note 12, at 122-127.

${ }^{29}$ On which, see Hans UlRich Wehler, DeUtSCHe GesellsChaftSGesChichte BAND 2 1815-1845/49, 95-107 (History of German Society, Volume 2, $4^{\text {th }}$ ed., 2005).

${ }^{30}$ See CoInG, supra note 12 , at 95-96.
} 
In this regard the coming of the railways played a decisive role as a spur to industrialization which, in turn, required the extension of the corporate legal form to railway companies. ${ }^{31}$ Accordingly, the first Prussian law to regulate the organization and operation of companies was the Law on Railway Companies (Gesetz über Eisenbahnunternehmungen) of $1838 .{ }^{32}$ Although railway companies still had to obtain a concession to incorporate, this law laid down general regulations for their operation and so it represents the first German attempt to place corporate governance on a modern normative legal footing. ${ }^{33}$ This was followed in 1843 by the first general corporate law for Prussia (Preussiche Aktiengesetz). ${ }^{34}$ The 1843 Law was largely based on the French Code de Commerce and the Dutch Commercial Code (Wetboek van Koophandel) of $1838 .^{35}$ Thus, it included limited liability, but it only covered joint stock companies and not sociétés en commandite. ${ }^{36}$

\footnotetext{
${ }^{31}$ See WEHLER, supra note 29, at 96, 614-631; for a comparative analysis of the role of railways in German, US and English industrialization between the 1830s and 1860s, see Rainer Fremdling, Railroads and German Economic Growth: A Leading Sector Analysis with a Comparison to the United States and Great Britain, 37 J. OF ECON. HIST. 583 (1977); see also Reich, supra note 16, at 249-250, on the connection between railway development and the corporate legal form.
}

32 GeSETZ ÜBER EISENBAHNUNTERnehmUngen (Railway corporate law) 3.11.1838 GS FUR DIE KONIGLICHEN PREUSSICHEN STAATEN 1838 (GS for Royal Prussian State), s. 505 (Ger.).

${ }^{33} \mathrm{REICH}$, supra note 16 , at 250; LEVY, supra note 7, at 98.

${ }^{34}$ Preussiche Aktiengesetz (Prussian corporation law) 9.11.1843 GS Fur Die Konglichen Preussichen STAATEN 1843,9 Nov. 1843, Nr 31 s.341 (Gr.). The following summary draws on REICH, supra note 16, at 251; LEVY, supra note 7, at 98-99, and GROSSFELD, supra note 12, at 127-131. See also GESETZ UBER DIE AKTIENGESELLSCHAFTEN FUR DIE KÖNIGLICH Preussischen StAATEN VON 9 November 1843 (Law on Companies for the Royal Prussian State, Theodor Baums ed., 1981). Other German States had also adopted corporate laws at this time. Thus, the Prussian and Bavarian Rhineland Provinces, Hessen and Baden, used the Code de Commerce after 1815 and only in the Prussian Rhine Province was it supplanted by the 1843 law. Wurttemberg codified its commercial law in 1839 and followed the Dutch Commercial Code in relation to corporations. Nassau codified its commercial law in 1842: REICH, supra note 16, at 243-244; WEHLER, supra note 29, at 104.

${ }^{35} \mathrm{REICH}$, supra note 16 , at 251; WESEL, supra note 18 , at 463 ; Coing, supra note 26 , at 169.

${ }^{36}$ LEVY, supra note 7, at 98-99. The basic principle behind the société en commandite is that it must comprise of at least two partners: the commandite, who is the managing partner and takes full liability for the commercial debts of the entity, and the commanditaire, who is a limited liability partner and who takes no part in the management of the undertaking. Such entities pre-date the French Code de Commerce: see LEVY, supra note 7, at 55. See also CODE DE COMMERCE, Art. L 222-1 (Fr.). 
The Law of 1843 was a concession law in that the corporate statute had to be assented to by the government. This would be given so long as the aims of the corporation were shown to be in the general interest. ${ }^{37}$ The corporate statute had to disclose the size of the initial capital, the method of accounting used and the nature of the voting rights for shareholders. The company had two organs: the Vorsteher, the main management organ and the general meeting (Generalversammlung). Thus, the initial model for the Prussian corporation was that of a single-tier board. The two-tier system was yet to evolve. The supervisory board (Aufsichtsrat) was unknown to the concession system. ${ }^{38}$ Prior to the 1843 Law, the duration of the company was limited by time though this was gradually increased from 15 to 20 to 25 and to 99 years. By section 2(2) of the 1843 Law, companies could exist in perpetuity but this was restricted in 1856 when it was required that the corporate statute should state a period of corporate existence. ${ }^{39}$ Initially, too, corporate objectives had to be limited to those permitted by the Prussian Ministerial Decree of 22 April 1845. However, after the 1850s, corporations with unspecified objects became more numerous. ${ }^{40}$

The general unease over the potential for abuse of corporate power would not last. Even before the 1843 Law, the Hanseatic City States were applying a normative system based on freedom of incorporation and, in addition to the Aktiengesellschaft, they used a German equivalent of the societe en commandite - the Kommanditgesellchaft auf Aktien. ${ }^{41}$ They argued for the general adoption of such a system when negotiations for an all-German Commercial Code began in Nuremberg in $1857 .^{42}$ They saw the concession system as arresting corporate investment and placing the state at the heart of corporate

\footnotetext{
${ }^{37}$ See also REICH, supra note 16 , at 253-254.

${ }^{38}$ Coing, supra note 26, at 172: the Code de Commerce "Dementsprechend kannte es das Konzessionssystem; dagegwen war die Institution des Aufrichtsrates unbekannt."

${ }^{39}$ GROSSFELD, supra note 12 , at 128.

${ }^{40}$ Id. at $130-131$.

${ }^{41}$ REICH, supra note 16, at 245; LEVY, supra note 7, at 101.

${ }^{42}$ REICH, supra note 16, at 260; GROSSFELD, supra note 12, at 134; Coing, supra note 26, at 173.
} 
regulation. ${ }^{43}$ This was not conducive to the further industrial modernization of $19^{\text {th }}$ century Germany. Nor was it clear that the concession system was superior to the normative system. It was apparent that it was unable to protect shareholders or creditors against abuse. ${ }^{44}$ Hamburg argued that the best defence against abuse was the oversight of the company's affairs by the shareholders. ${ }^{45}$ Nonetheless Prussia and the majority of German States resisted the Hanseatic States. A compromise was reached in the All-German Commercial Code (Allgemeines Deutsches Handelsgesetzbuch, ADHGB) of 1861, whereby each German State was empowered to determine for itself whether it would continue with a concession system or move towards freedom of incorporation. ${ }^{46}$ Thus, the Nuremberg Conference failed to resolve what type of corporate legal form and what type of incorporation should found the all-German system. As a result, different State systems of corporate law remained. 47

\section{The Establishment of Modern Corporation Law, 1870 to 1897}

The multiplicity of State corporation laws could not last. The unification of Germany and the economic need for easy access to the limited liability corporate form gave impetus for a unified German corporate law based on a normative system of free incorporation. Not only were England and France moving towards freedom of incorporation, respectively under the English Companies Act 1862 and the French Loi sur les Sociétés a Responsabilité Limite of 1863 , but calls for the final abolition of the concession system in Germany had become irresistible under the banner of "Freigabe des Aktienwesens." 48

Equally, fears over the competitive impact of corporations began to recede during the 1860s. Most corporations were fairly small and the corporate form was seen as suitable

\footnotetext{
${ }^{43}$ REICH, supra note 16 , at 255; Wehler, supra note 29 , at 105-106.

${ }^{44}$ Grossfeld, supra note 12 , at 134.

${ }^{45}$ REICH, supra note 16 , at 260 .

${ }^{46}$ GROSSFELD, supra note 12, at 134-135, citing Art. 249 of the ADHGB: "Den Landegesetzen bleibt es vorbehalten zu bestimmen, dass es der staatlichen Gehnemigung zur errichtung von Aktiengesellschaften im allgemienem oder von einzelnen Arten derselbern nicht bedarf."

${ }^{47}$ Reich, supra note 16 , at $261-262$.

${ }^{48}$ See Reich, supra note 16 , at 264-265.
} 
only in certain sectors of the economy, while the risk of abuse of market power could be controlled by an effective normative system rather than by concessions. ${ }^{49}$ Indeed, competition would be enhanced if freedom of incorporation was to be available, as it would allow for more business associations to arise. ${ }^{50}$

In response to these influences, the North German Bund began to debate a new allGerman corporate law in 1870 in the context of the proposed reform of the ADHGB. Once again, Prussia was skeptical about how far freedom of incorporation could go, while the Hanseatic Cities wanted full liberalization. ${ }^{51}$ Prussia carried the majority of German States. Thus, while the 1870 Law applied to both Kommanditgesellschaften auf Aktien (KGaA) and Aktiengesellschaften (AG), and permitted the establishment of a company by registration, it contained numerous formalities and restrictions on company formation, ${ }^{52}$ introduced a prohibition on dividend distribution where this would weaken the capital of the company, a prohibition on dealing in its own shares by the company, a prohibition on the company's supervisory and management board members entering into transactions with the company

\footnotetext{
${ }^{49}$ GROSSFELD, supra note 12 , at $136-137$.

${ }^{50}$ Id. at $137-138$.
}

${ }^{51}$ For a detailed analysis of the discussions leading to the 1870 Law, see Werner Schubert, Die Abschaffung des Konzessionssystems durch die Aktienrechtnovelle von 1870 (The abolition of the concession system by the Company Law Amendment of 1870), 10 ZEITSChRIFT FÜR UNTERNEHMENS- UND GESELLSCHAFTSRECHT 2, 285 (1981), available at: http://www.degruyter.com/dg/viewarticle/j\$002fzgre.1981.10.issue2\$002fzgre.1981.10.2.285\$002fzgre.1981.10.2.285.xml;jsessionid=5ECE5F7390DE5D53017F5B595FDA4F2F (last accessed: 1 February 2013). For a more general overview of the codification process, see Klaus Hopt, Ideelle und wirtschafliche Grundlagen der Aktien-Bank- und Borsen rechtsentwicklung in 19. Jahrhundert, in WISSENSCHAFT UNDE KODIFIKATION DES PRIVATRECHTS IM 19. JAHERHUNDERTS 128 (The science and codification of private law, Helmut Coing \& Walter Wilhelm eds., 1980).

52 GesetZ betreffend die Kommanditgesellschaften Auf AkTIEn und die AkTiengesellschaften, 11 June 1870, s. $375-386$ Artikel (Art.) 210a and Art. 211: "Der Anmeldung Behufs der Eintragung in das Handelsregister muß beigefügt sein: 1) die Bescheinigung, dass der gesammte Betrag des Grundkapitals durch Unterschriften gedeckt ist; 2) Die Bescheinigung, dass mindestens zehn Prozent, bei Versicherungsgesellschaften mindestens zwanzig Prozent, des von jedem Aktionair gezeichneten Betrages eingezahlt sind; 3) der Nachweis, dass der Aufsichtsrath nach Inhalt des Vertrages in einer Generalversammlung der Aktionaire gewählt ist; 4) betreffenden Falls die gerichtliche oder notarielle Urkunde über die in den Artikeln 209a und 209b bezeichneten Beschlüsse der Generalversammlung. Die Anmeldung muß von sämmtlichen Mitgliedern des Vorstandes vor dem Handelsgericht unterzeichnet oder in beglaubigter Form eingereicht werden. Die der Anmeldung beigefügten Schriftstücke werden bei dem Handelsgericht in Urschrift oder in beglaubigter Abschrift aufbewahrt." 
unless a 2/3rds majority of the General meeting approved, and new accounting rules and criminal penalties. ${ }^{53}$

Most significantly, the 1870 Law required the use of the Aufsichtsrat (or Aufsichtsrath in the original), at least in relation to the AG, to replace the State authorization and oversight of the concession system. ${ }^{54}$ The Aufsichtsrat was available as an optional organizational device under Art.225 of the ADHGB in relation to KGaAs, but it was the 1870 Law that gave legal force to the two tier board structure. ${ }^{55}$ However there was confusion as to whether the Aufsichtsrat was also compulsory for the KGaA, and this had to be clarified by the 1884 Law, which stated that both corporate forms had to have an Aufsichtsrat. ${ }^{56}$ Again, the 1870 Law was influenced by foreign developments, as the idea of a supervisory organ was taken from French law. 57

The 1870 Law had immediate impact. Following victory in the Franco-Prussian War of 1870-71, and the consequential boost to the German economy from war reparations and

\footnotetext{
${ }^{53}$ Schubert, supra note 51 , at 302-312.

${ }^{54}$ Schubert, supra note 51 , at 306.
}

${ }^{55}$ Adolf Cahn, Der AufSichtSRat der AkTiengesellschaft 6-10 (The Supervisory Board of the Corporation, 1907). For a detailed historical analysis of the rise of the Aufsichtsrat in German law, see Tanja Schnorr, Historie und Recht des Aufsichtsrats - Deutsche Erfahrungen als Beitrag zum Statut der Europäischen Aktiengesellschaft 1991 (Inaugural-Dissertation Zur Erlangung der Würde eines doctor iuris der Juristischen Fakultät der Bayerischen Julius-Maximilians-Universität Würzburg, 2000), available at: http://ebookbrowse.com/diss-tanja-schnorr-pdfpdf-d89249780 or http://d-nb.info/971589054/34 (last accessed: 1 February 2013).

\footnotetext{
${ }^{56}$ See LEVY, supra note 7, at 128; REICH, supra note 16, at 267-268; Coing, supra note 26, at 173. GESETZ BETREFFEND

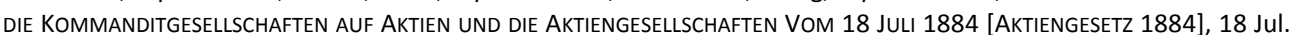
1884, Deutsches ReichsgeSETZBLATt BAND 1884, Nr 22 s. 123-170 Art. 175e (Ger.): “Jede Kommanditgesellschaft auf Aktien muss einen Aufsichtsrath haben", Art. 209f: "Jede Aktiengesellschaft muss ausser dem Vorstande einen Aufsichtsrath haben."
}

\footnotetext{
${ }^{57}$ Coing, supra note 26, at 173 . Some dispute exists as to how this idea was taken from French to German law with the suggestion made by Passow, rejected by Levy, that German legislators had wrongly translated the French Conseil de Surveillance literally when they only intended the supervisory organ to be an advisory body to the management board based on the German Verwaltungsrat: see LEVY, supra note 7, at 129. Francks, Mayer and Wagner accept Passow's view: Julian Franks, Colin Mayer \& Hannes Wagner, The Origins of the German Corporation - Finance, Ownership and Control, 10 REV. OF FIN. 537 (2006). They cite Richard Passow, Die Entstehung Des Aufsichtsrats der Aktiengesellschaft, 64 ZEITSCHRIFT FUER DAS GESAMTE HANDELSRECHT UND KONKURSRECHT, 27-57 (1909), and RICHARD PASSOW, Die AKTIENGESELLSCHAFT: EINE WIRTSCHAFTSWISSENSCHAFTLICHE STUDIE (The Corporation: An Economic Study, $2^{\text {nd }}$ ed., 1922).
} 
German unification, a "Founders Boom" (Gründerboom) spurred a wave of new incorporations under the new corporation law. ${ }^{58}$ However, by 1873 the boom turned to bust (the Founders Crash - Gründungskrach) and much of the blame for the ensuing wave of fraudulent corporate failures (the Gründerschwindel) was placed at the feet of the 1870 Law. $^{59}$ In particular, the minimum capital requirement of $10 \%$ for the formation of a company was too low to prevent overvalued corporate promotions, the registration process before the Commercial Court was a mere formality without proper oversight, the Aufsichtsrat and the Generalversammlung were incapable of performing their oversight duties, and numerous manipulations of share prices created a bubble. ${ }^{60}$

In response, reform of the law of 1870 was thought essential. However, this was to take until 1884, given much debate as to the proper way forward. ${ }^{61}$ According to Reich, at least three alternative approaches were contesting the agenda. The first was outright abolition of the corporate legal form, which could not survive Germany's espousal of market capitalism, the second was to limit the corporate sphere of operations, thereby effectively avoiding a general corporation law, while the third retained the liberal commitment to complete freedom of incorporation. This could not survive the effect of the Gründerschwindel. The resulting compromise was to retain a general corporate law with freedom of incorporation but with greater controls over corporate operations and protection against abuses.

The resulting Law of 1884 covers both the $\mathrm{KGaA}$ and the AG. ${ }^{62}$ It focuses on the process of incorporation and the formalities required, including full disclosure of corporate funds and

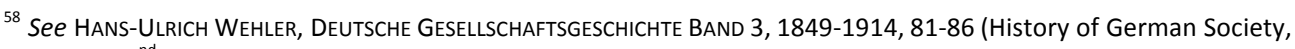
Volume $3,2^{\text {nd }}$ ed., 2006).

${ }^{59}$ See REICH, supra note 16 , at 268.

${ }^{60} / d$.

${ }^{61}$ See REICH, supra note 16 , at 270-276, on which the following paragraph relies, and Grossfeld above n.12 at 144 145. See also, Hundert Jahre Modernes Aktienrecht: Sammlung von Texten und Quellen zur Aktienrechtsreform 1884 (One Hundred Years of Modern Company Law: Collection of Texts and Sources on Corporate Law Reform, Werner Schubert \& Peter Hommelhoff eds., 1985).

${ }^{62}$ GeSetZ betreffend die Kommanditgesellschaften Auf AKTIEN UNd die AKTIEngeSellschaften Vom 18 Jul 1884, supra note 56. For a brief summary in English, see LEVY, supra note 7, at 128-131.
} 
details in a prospectus and the setting up of an Aufsichtsrat (Aufsichtsrath). ${ }^{63}$ The 1884 Law follows the 1870 Law in requiring an issue to be subscribed to a minimum of 1000 marks and at least 25\% (200 Marks) of the capital to be paid up upon establishment. ${ }^{64}$ Failure to comply with the formalities of accurate disclosure would result in the personal liability of the founding members and supervisory board members. ${ }^{65}$ In cases of knowingly false disclosure criminal penalties were provided for. ${ }^{66}$ Corporations had to file annual profit, loss and balance statements. ${ }^{67}$ Further protections included rules covering changes in the articles of association and in the capital of the corporation, ${ }^{68}$ and controls over share transactions, including a prohibition against dealing by the corporation in its own shares. $^{69}$ The 1884 Law guaranteed limited liability for shareholders, ${ }^{70}$ while the personal liability of supervisory board members would be based on the principle of the ordinary reasonable businessman. ${ }^{71}$ In addition, minority shareholder protection and shareholder remedies were included. ${ }^{72}$ Corporate organization under the 1884 Law requires, both for the KGaA and AG, a general meeting (Generalsammlung) and an Aufsichtsrat elected by

\footnotetext{
${ }^{63}$ GeSetz betreffend die Kommanditgesellschaften auf AKTien und die AKTiengesellschaften Vom 18 Jul 1884, supra note 56, for KGaA at Arts. 175-179, for AG Arts. 207-212.

${ }^{64}$ Id., for KGaA, Art. 173a; for AG, Art. 207a.

${ }^{65}$ Id., for KGaA, Arts. 180-180b and Art. 193 on duties of the supervisory board members; for AG, Arts. 213-213c.

${ }^{66} / d .$, Arts. 249-249g.

${ }^{67}$ Id., for KGaA, Arts. 185-185c; for AG, Art. 239.

${ }^{68}$ Id., for KGaA, Arts 180f-180i; for AG, Arts. 215 and 215a.

${ }^{69}$ Id., for KGaA, Arts. 181-183a, 184-184d; for AG, Arts. 215b-215d.

${ }^{70}$ Id., for KGaA, Art. 183b; for AG, Art. 219.

${ }^{71}$ Id., for KGaA, Art. 204: "die sorgfalt eines ordentlichen Geschaftsmanns anzuweden"; for the AG, Art. 226.

72 Id., for KGaA and AG, Art. 190 (ensuring that each shareholder has a vote in the General Meeting and larger shareholders could be subjected to limits in voting); for AG shareholder remedies, see Arts. 221-223.
} 
the former. ${ }^{73}$ In the case of the AG, the two-tier structure requires full separation of the Aufsichtsrat and the management board (Vorstand). ${ }^{74}$

The principal provisions of the 1884 Law were codified into the $H G B$ of $1897 .{ }^{75}$ This made a number of changes, including the strengthening of control over incorporation and increases and decreases in the capital of the corporation, new rules permitting the inclusion of rules on recurrent contributions in goods in the articles of association and increased rights for minority shareholders, who could now bring an action against persons liable to the corporation based on $10 \%$ of the share capital instead of $20 \%{ }^{76}$

The two tier structure of the post- 1870 German corporation has been the subject of recent historical debate. In particular, two connected issues stand out for lawyers: the role of the Aufsichtsrat in contributing to the 'insider' system of corporate governance and finance through the presence of investment banking interests among its members, and the role of investment banks in the process of German industrial concentration and the rise of the Konzerne.

The controlling role of investment banks is explained by Alexander Gerschenkron, according to whom Germany, as a moderately backward country, required that universal banks supplied finance and guided industrial growth. ${ }^{77}$ Subsequent economic studies have

${ }^{73}$ Id., for KGaA, Art. 175e and Art. 191, which also applies to AGs under Art.224.

${ }^{74}$ Id., Art. 225a. The supervisory function of the Aufsichtsrat is established by Art. 225. On the duties of the Vorstand, see Arts. 227-241. Members of the Vorstand are also subject to the duty of care of the ordinary businessman: Art. 241.

${ }^{75}$ Deutsche Handelsgesetzbuch Vom 10 Mal 1897 [RGBI], 1 Jan. 1900, s. 219.

${ }^{76}$ See Levy, supra note 7, at 132-133; see also JAN VON HEIN, DIE REZEPTION US-AMERIKANISCHEN GESELLSCHAFTSRECHTS IN DEUTSCHLAND 99-100 (Reception of United States Corporate Law in Germany, 2008), who notes that little comparative law analysis infomred the codification of 1897.

77 Alexander Gerschenkron, The Modernisation of Entrepreneurship, in CONTINUITY IN HISTORY AND OTHER ESSAYS (1968), at 137: "The German investment banks - a powerful invention, comparable in economic effect to that of the steam engine - were in their capital-supplying functions a substitute for the insufficiency of the previously created wealth willingly placed at the disposal of entrepreneurs." See also Alexander Gerschenkron, The Approach to European Industrialization: A Postscript, in ECONOMIC BACKWARDNESS IN HISTORICAL PERSPECTIVE 353-354 (1962). 
reinforced this view. ${ }^{78}$ German corporate law is seen as instrumental in this process of bank domination. Bank representatives could sit on the supervisory boards of companies. When these were made compulsory under the 1884 Law, Gerschenkron argued that this furthered the influence of universal banks over the German corporate system and led to the increased concentration of German industry through inter-locking directorships and mergers. 79

This has become a contentious issue given more recent research findings by economic historians of Germany. Several studies point out that the universal banks wielded less influence than the conventional view suggests. ${ }^{80}$ The historical evidence shows that investment banks could influence the supervisory board, especially where they held proxy votes by reason of their role as intermediaries in securities markets. This allowed investment banks to insert clauses in their terms of business, permitting them to exercise proxy votes on behalf of their shareholding customers, thereby complying with the legal requirement that proxy voting could only occur upon the express permission of the

\footnotetext{
${ }^{78}$ For an overview, see CARoline Fohlin, FINANCE CAPITALISM AND GERMANY's RISE to INDUSTRIAL POWER 31-37 (2007).

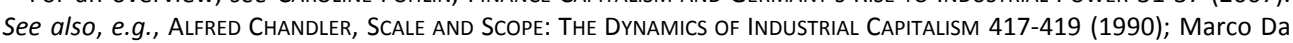
Rin \& Thomas Hellmann, Banks as Catalyst for Industrialisation, 11 J. OF FIN. INTERMEDIATION 266 (2002); TONI Pierenkemper \& Richard Tilly, The German EConomy During the Nineteenth Century (2004), at Chatper 7; for a Marxist interpretation, see RUdolpH HILFERDING, FINANCE CAPITAL (1910) (Tom Bottomore trans., 1981); see also Marco Da Rin, Understanding the Development of German Kreditbanken, 1850-1914: an Approach from the Economics of Information, 3 FIN.'L HIST. REV. 29 (1996), who argues that the development of effective systems for information gathering by the universal banks was key to their ability to control industrial enterprises in which they held an interest.
}

\footnotetext{
79 See FoHLIN, supra note 78, at 33-34, citing Gerschenkron: "[T]hrough the development of the institution of the supervisory boards to the most powerful organs within corporate organisations, the banks acquired a formidable degree of ascendancy over industrial enterprises, which extended far beyond the sphere of financial control into that of entrepreneurial and managerial decisions." See, on the impact of the 1884 Law on corporate concentration, Norbert Reich, Auswirkungen der deutschen Aktienrechtsreform von 1884 auf die Konzentrazion der deutschen Wirtschaft, in RECHT UND ENTWICKLUNG DER GROSSUNTERNEHMEN IM 19. UND FRUHEN 20 JAHRHUNDERT; LAW AND THE FORMATION OF BIG ENTERPRISES IN THE $19^{\text {TH }}$ AND EARLY $20^{\text {TH }}$ CenTURIES 255-273 (Norbert Horn \& Jurgen Kocha eds., 1979). See also, Norbert Horn, Aktienrechtliche Unternehmensorganisation in der Hochindustialisierung (1860-1920) Deutschland, England, Frankreich und die USA im Vergleich, in RECHT UND ENTWICKLUNG DER GROSSUNTERNEHMEN IM 19. UND FRUHEN 20 JAHRHUNDERT; LAW AND THE FORMATION OF BIG ENTERPRISES IN THE $19^{\text {TH }}$ AND EARLY $20^{T H}$ CENTURIES, 123-189 (Norbert Horn \& Jurgen Kocha eds., 1979).
}

${ }^{80}$ See PIeRENKEMPER \& TILly, supra note 78, at 120-121; Jeremy Edwards \& Sheilagh Ogilvie, Universal Banks and German Industrialization: a Reappraisal, XLIX ECONOMIC HISTORY REVIEW 427 (1996); for a summary of the main authorities for and against the bank dominance thesis, see FoHLIN, supra note 78, at 40-44. 
shareholder. ${ }^{81}$ Consequently, banks could exert influence through the general meeting as to long-term strategic decisions and the composition of the supervisory board. ${ }^{82}$

However, when the economic context is analyzed, the resulting picture suggests at least the possibility of lesser influence. First, the incidence of bank representation on the supervisory board is limited to certain sectors of heavy industry, specifically mining, transport and the electro-technical sectors. ${ }^{83}$ These represent only a small proportion of all industrial firms. By 1913 only $17.7 \%$ of total industrial capital stock was held by joint stock companies. ${ }^{84}$ The majority of industrial enterprises in this period were small and medium sized firms (SMEs) of the Mittelstand. They were locally funded by a variety of small savings and cooperative banks (which may or may not have had seats on the board), though this varied by region and industry, reflecting the relatively decentralized nature of the German economy. ${ }^{85}$ Even the major industrial concerns of the first era of German industrialization, the railways, were mostly funded by the state, except in Prussia, where funding was organized through joint stock corporations incorporated by concession. ${ }^{86}$

Secondly, the alleged power of the banks does not match up to the actual use of investment bank finance by corporations. The largest industrial concerns were able to reinvest their own funds and bank finance was used in specific cases to cover for long returns on investment or to weather a short term crisis. ${ }^{87}$ The apparent influence of the banks would only appear where their views coincided with those of the main industrial

${ }^{81}$ Franks, supra note 57 , at 7; FOHLIN, supra note 78, at 121-125.

${ }^{82}$ FOHLIN, supra note 78 , at 122.

${ }^{83}$ For detailed data on the actual numbers of bank members of supervisory boards, bank shareholding patterns in non financial firms and interlocking directorships of bank representatives, all of which, she asserts, show more limited involvement than the Gerschenkron thesis supposes, see FoHLIN, supra note 78, at 43 and Chapter 5. However, not all proponents of the bank dominance thesis are convinced: see note 101, infra.

${ }^{84}$ Edwards, supra note 80 , at 436.

${ }^{85}$ See also, Richard Deeg, On the Development of Universal Banking in Germany, in THE ORIGINS OF NATIONAL FinANCIAL SySTEMS: ALEXANDER GeRSCHENKRON ReCONSIDERED 87 (Douglas Forsyth \& Daniel Verdier eds., 2003).

${ }^{86}$ Edwards, supra note 80 , at 434.

${ }^{87}$ Id. at $437-440$. 
owners and managers, who retained overall control of business policy. ${ }^{88}$ Indeed, Neuberger suggests that the notion of bank domination can be tested by reference to the close personal, and even family, ties between leading industrialists and senior figures in the investment banking community, which puts the relationship on rather different and more equal ground. ${ }^{89}$ Furthermore, where firms merged, funding would often involve numerous banks that were part of a consortium. Their influence would be limited by internal competition between them. ${ }^{90}$

A further complicating factor concerns the timing of the rise of universal banks and the process of German industrial development, which, as noted above, can be dated from railway development in the mid $19^{\text {th }}$ century. As Fohlin notes,

"[t]he era of formal bank control must... have been shorter than the traditional account suggests. Since there were few joint stock companies to control before 1870 , and since half of the great banks were founded after 1870 , the period of universal bank domination, if it ever existed, could have spanned at most two decades - the 1870s and 1880s. It is therefore difficult to reconcile the idea of bank power with the actual timing of events." 91

Though there is evidence of bank involvement in the supervisory boards of certain sectors of heavy industry during this period, that evidence is now known to be based on a small non-representative set of firms over a limited period of time and is drawn largely from a small number of contemporary authors who were either directly involved in the banking sector or, like Rudolf Hilferding, were socialist critics of "finance capitalism." 92

${ }^{88}$ See WEHLER, supra note 58, at 630; see also LEVY, supra note 7, at $128,142-145$, who notes that supervisory boards were not very effective at control over managers and that managers acquired the upper hand over the aufsichtsrat and the generalversammelung.

${ }^{89}$ Hugh Neuburger, The Industrial Politics of the Kreditbanken, 1880-1914, 51 BUS. HIST. REV. 190 (1977).

${ }^{90}$ Edwards, supra note 80 , at 440.

${ }^{91}$ See FoHLIN, supra note 78 , at 43.

92 See Fohlin, supra note 78, at 45, citing JACOB REISSER, DIE DEUTSCHEN GROSSBANKEN UND IHRE KONZENTRATION (The German banks and their concentration, 1910), who was a director of one of the universal banks, OTTO JEIDELS, DAS VERHALTNIS DER DEUTSCHEN GROSSBANKEN ZUR INDUSTIRE (The relationship of German banks for industry, 1905), who was a bank employee, and HILFERDING, supra note 78. For criticisms of Hilferding's analysis, see WEHLER, supra note 58, at 630; see also, Neuberger, supra note 89, who doubts that the evidence of the "dictatorship of the banks" asserted by Hilferding and Gerschenkron can survive empirical analysis. Subsequent research has proved him correct. 
Indeed, by 1900 it would appear that the power of banks was on the wane, especially in the mining and steel industries, where most of the research showing bank domination had focused, and before the era of greatest industrial concentration in the early $20^{\text {th }}$ century. ${ }^{93}$

Finally, the bank domination thesis can be challenged by the existence of a parallel system of corporate finance in late $19^{\text {th }}$ century Germany, which allowed for the co-existence of bank finance with active stock markets. ${ }^{94}$ Indeed the rise of stock markets in late $19^{\text {th }}$ century Germany was facilitated by the freedom of incorporation under the Laws of 1870 and 1884. Equally, the shareholder protection standards introduced by the 1884 Law furthered this goal.

Subsequent legislative developments do not contradict the facilitative role of German Law. In particular, the strengthening of shareholder protection standards in the 1896 Börsengesetz, following on from severe stock price declines and sensational cases of embezzlement and other stock transaction abuses, created a better level of protection for shareholders than could be found in contemporary English laws. ${ }^{95}$ The 1896 Law allowed for tighter listing requirements and created new institutions to oversee new share issues, the Staatskommissar, the judicial Ehrengericht and an expert committee, the Börsenausschuss. $^{96}$ It also covered the regulation of conversion of private firms into AGs, which became the most significant type of corporate floatation on the stock market by the early years of the $20^{\text {th }}$ century. ${ }^{97}$ Together, these changes should have improved confidence in exchanges and promoted the greater use of securities and equities. ${ }^{98}$

${ }^{93}$ FoHLIN, supra note 78 , at $41-43$, and the sources cited therein.

\footnotetext{
${ }^{94}$ See e.g., FOHLIN, supra note 78, and Caroline Fohlin, Does Civil Law Tradition and Universal Banking Crowd out
} Securities Markets?, 8(3) ENTERPRISE AND SOC. 602 (2007).

95 Franks, supra note 57, at 4-5. See further, WolfGANG SCHULTZ, DAS DEUTSCHE BORSENGESETZ: DIE ENTSTEHUNGSGESCHICHTE UND WIRTSCHAFLICHEN AUSWIRKUNGEN DES BORSENGESETZES VON 1896 (The German Stock Exchange Act: The History and Economic Impact of the Exchange Act, 1994); for a critical contemporary appraisal, see Ernst Loeb, The German Exchange Act of 1896, 11 THE QTR'LY J. OF ECON. 388 (1897), available at: http://www.jstor.org/stable/1880717?origin=JSTOR-pdf (last accessed: 1 February 2013).

\footnotetext{
${ }^{96}$ Fohlin, supra note 94 , at 615.

${ }^{97} / d$.

${ }^{98}$ FoHLIN, supra note 78 , at 232.
} 
However, the 1896 Law has been held up as an example of German suppression of securities markets because it also prohibited futures trading contracts in the securities of mining and manufacturing enterprises. According to Fohlin, this was a result of successful lobbying by Prussian landed interests rather than a principled attack on securities markets and so cannot be seen as evidence of official opposition to this type of financing in favour of universal bank lending. ${ }^{99}$ The ban was lifted in 1908, but the impact of the prohibition on banking concentration, caused by increased demand for banks to provide futures trading facilities through expanding networks, could not be reversed. ${ }^{100}$

Thus, one central feature commonly associated with German corporate law, the domination of the Aufsichtsrat by universal investment banks, leading to concentration and policy coordination between businesses, is open to debate so far as the $19^{\text {th }}$ century is concerned, though the more traditional position remains influential. ${ }^{101}$ Equally, German industrial concentration in this period is perhaps no different from the same processes in other industrializing nations and can be better explained by reference to economic factors rather than as a result of peculiar local legal factors. ${ }^{102}$ It would appear that the most important variable for firm concentration in this period in Germany, the US and the UK is external growth conditioned by capital market conditions. ${ }^{103}$

The facilitative role of law in this process is best seen in the abolition of prohibitions over a corporation owning shares in another. ${ }^{104}$ According to Grossfeld, this was known in Germany in the 1840s and was accepted by the German Supreme Commercial Court

\footnotetext{
${ }^{99}$ Fohlin, supra note 94 , at 616-617.

${ }^{100} / d$. at 618 .

${ }^{101}$ See further, the critique of Fohlin's views by Alexander Dyke, in his response to Caroline Fohlin, The History of Corporate Ownership and Control in Germany, in A HISTORY OF CORPORATE GOVERNANCE AROUND THE WORLD: FAMILY BusinesS GROUPS to PROFESSIONAL MANAGERS 277-281 (Randall Morck ed., 2005).

102 See further Leslie Hannah, Mergers Cartels and Concentration: Legal Factors in the US and European Experience, in Horn, supra note 78, at 306-316.

${ }^{103}$ See Richard Tilley, External Growth, and Finance in the Development of Large-Scale Enterprise in Germany, 1880-1913, 42 J. OF ECON. HIST. 629 (1982).

${ }^{104}$ See Peter Muchlinski, Multinational Enterprises And the LaW 35 (2007).
} 
(Reichsoberhandelsgericht) in 1877, which held that the corporation could own shares in the same manner as a natural person. ${ }^{105}$ The 1884 Law required the registration of branches in the Commercial Court handling the registration process but contained no specific rules on corporate groups, a feature of later German laws. ${ }^{106}$

Grossfeld further asserts that the rise in concentrations was assisted by the fact that cartels were seen as lawful by the German courts in the late $19^{\text {th }}$ century and this led to an acceptance of corporate groups, although a holding company could be prohibited under Art.43 of the Bürgerliches Gesetzbuch where it was seen as endangering the public interest. $^{107}$

The relationship between merger activity and the legal regulation of cartels is a problematic issue. Tilley suggests that differing levels of merger activity could be attributed to different levels of incorporation and the presence or absence of prohibitions on cartels, suggesting that the high level of merger activity in the US at this time was in part a result of the prohibition of cartels in US law, while cartels remained lawful in Britain and Germany. ${ }^{108}$ On the other hand, as Cornish argues, the actual relationship between anticartel laws and industrial concentration cannot be explained by a simple cause and effect analysis as it involves a myriad of legal factors and business judgments that need to be assessed by the businesses in question, including the risk of enforcement actions. Therefore, a more case specific approach is needed. ${ }^{109}$

Also open to debate is the idea that the Kaiserreich actively encouraged industrial concentration and the rise of "Corporatism" (Korporatismus) beyond a legal tolerance of cartels. ${ }^{110}$ As noted above, the impact of the various corporate laws and of the

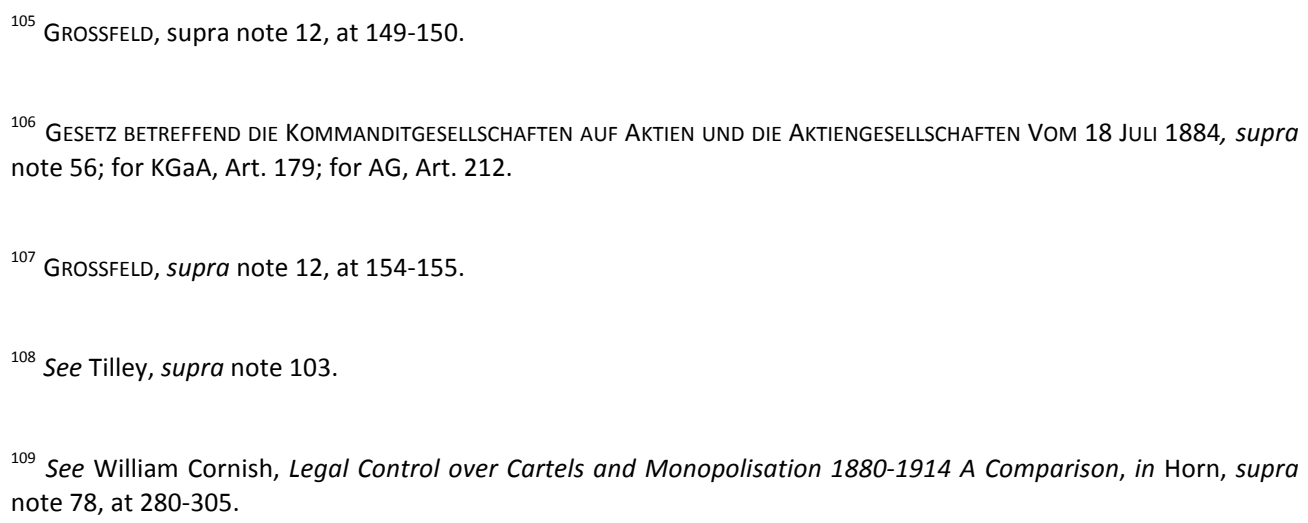

110 "Corporatism" is used here to denote a system of industrial organisation in which the State co-ordinates, or directs, corporate and sectoral policy in co-operation with the representatives of business and industry and, 
Börsengesetz was broadly facilitative for business. ${ }^{111}$ Furthermore, it is uncertain that the central government could act in this way, given the reality of relatively de-centralized government and economy in Germany at the time and the dominant force of economic liberalism in the politics of the age. ${ }^{112}$ Thus, the rise of German corporatism as a major influence on the development of corporate law belongs to a later period.

The remaining development in this period is the extension of the limited liability corporate form to SMEs, through the GmbH. This was introduced under the Gesetz Betreffend die Gesellschaften mit Beschränkter Haftung of $1892 .^{113}$ The $\mathrm{GmbH}$ is a capital holding entity with separate legal personality from its members and limited liability. ${ }^{114}$ This was established for small groups of shareholders with close personal links, who would not ordinarily trade their shares, but who needed a form of limited liability association that

where politically acceptable, organised labour and worker representatives. On the problems of this concept, see Leo Panitch, Recent Theorizations of Corporatism: Reflections on a Growth Industry, 31 BRIT. J. OF SOC. 159 (1980). On the historical roots of German corporatism in the Kaiserreich, see WEHLER, supra note 58, at 662-680.

${ }^{111}$ See further vON HEIN, supra note 76 at 143, who argues that the reforms of 1870 and 1884 were typical products of liberalism based on private law principles that were compatible with the basic premises that informed English and French law of the time. To have considered these laws as interventionist at that time would have appeared as a relapse into the concession system which they had been adopted to replace. In a similar vein, see F.A. Mann, The New German Company Law and its Background, 19 J. COMP. LEGIS. \& INT'L L. 3D SER. 220, at 223 (1937). See also Richard Overy, State and Industry in Germany in the Twentieth Century, 12(2) GERMAN HISTORY 180 (1994), who notes (at 181) that in the period from the late 19th century to 1916, "[t]he state certainly interfered more in German economic life than was the case in Britain or the United States, but the gap should not be exaggerated. Industry did much of its own regulating, through cartels and trusts. When war broke out in 1914, it was industry that took up the challenge of war production...Up to 1916 the domestic war economy was still left mainly to private initiative. " For the argument that the reform of 1884 represented a non-liberal position, see

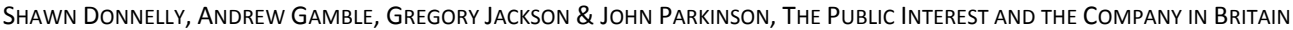
AND GERMANY 13-16 (2000), available at: http://www.agf.org.uk/cms/upload/pdfs/CR/2000 CR1215 e public interest and the company.pdf (last accessed: 1 February 2013).

${ }^{112}$ Fohlin, supra note 94 , at 609-611.

113 Gesetz Betreffend die Gesellschaften mit Beschrankter Haftung vom 20 April 1892 (Law Concerning Private Limited Companies, 20 April 1892) [GMBH GESETZ 1892], 20 Apr. 1892, as amended, available at: http://www.gesetze-im-internet.de/bundesrecht/gmbhg/gesamt.pdf (last accessed: 1 February 2013). For a useful brief summary, see Coing, supra note 12, at 127-130.

${ }^{114}$ GMBH GeSETZ 1892, supra note 113, Art. 13. 
was not as complex or inflexible in its formation and conduct as the AG. ${ }^{115}$ Accordingly, the $\mathrm{GmbH}$ is subject to simplified rules on formation and does not need to have a supervisory board, though in practice many of today's larger $\mathrm{GmbHs}$ have one. ${ }^{116}$ Space prevents a more detailed discussion save for noting that the $\mathrm{GmbH}$ has lived in the shadow of the $A G$ in comparative corporate law literature, which tends to stress the role of the joint stock corporation as the main vehicle for industrial development, despite the fact that most German business enterprises of the period do not adopt that legal form. ${ }^{117}$

\section{German Corporate Law 1897-1945}

The corporate law system described in the previous section remained in place until the Emergency Corporate Law Measures of 1931 (Notverordnung - NotVO), ${ }^{118}$ followed by the

\footnotetext{
115 See ANDENAS \& WOOLDRIDGE, supra note 10, at 116, and further, for an account of the origins of the $G m b H$, see Timothy Guinnane, Ron Harris, Naomi Lamoreaux \& Jean-Laurent Rosenthal, Putting the Corporation in its Place, 8(3) ENTER. AND SOC'Y 687, 697-703 (2007). They stress the difficulties of incorporation under the 1884 Law as a factor in the development of the $\mathrm{GmbH}$. Perhaps, the answer lies in the nature of German business ownership of the time and in the continued importance of family owned enterprises and of smaller entities that did not need, or want, the $A G$ form but wanted limited liability.
}

${ }^{116}$ See e.g., BUNDESVERBAND DER DEUTSCHEN INDUSTRIE E. V. [BDI] [Federation of German Industries], MAJOR FAMILY BUSINESSES IN GERMANY FACTS, FIGURES, POTENTIAL 21 (2012), available at: http://www.ifmbonn.org/assets/documents/BDI-major-family-businesses-Spring-2012.pdf (last accessed: 1 February 2013); family run $\mathrm{GmbH}^{\prime}$ s may have a supervisory board due to provisions in the company contract or as a result of the requirements of the Co-determination Laws.

${ }^{117}$ See also Guinnane, supra note 115 , undertaking a comparative study of the development of private limited liability corporations in the UK, US, France and Germany. On the $19^{\text {th }}$ century figures, see Edwards, supra note 80. Contemporary figures show that the SME sector still dominates the German economy. According to the German Federal Ministry of Economics and Technology, "Small and medium-sized companies in Germany represent $99.7 \%$ of all businesses, produce $38 \%$ of taxable turnover, account for nearly $49 \%$ of total net value added by companies, and provide roughly $60 \%$ of all jobs requiring social insurance contributions." See Federal Ministry of Economics and Technology, Policy for small and medium-sized businesses (2012), available at: http://www.bmwi.de/English/Navigation/Economic-policy/small-business-policy.html (last accessed: 1 February 2013).

118 VeroRdNung deS REICHSPRESIDANTEN UBER AKTEINRECHT, BANKENAUSSICHTT UND UBER DIE STEUERAMNESTIE VOM 19 September 1931 Reichsgesetzblatt [RGBI], 19 Sep. 1931, Historische ReChtS- Und Gesetzestexte ONLINE OSTERREICHISCHE NATIONALBIBLIOTEK, Teil $1 \mathrm{Nr} .63$ s.493, ALEX available at: http://alex.onb.ac.at/cgicontent/alex?aid=dra\&datum $=1931 \&$ page $=591 \&$ size $=45$ (last accessed: 1 February 2013). More generally, see Richard Rosendorff, The New German Company Act and the English Companies Act 1929, Part I, 14 J. COMP. LEGIS. \& INT'L L. 3D SER. 94 (1932), Richard Rosendorff, The New German Company Act and the English Companies Act 1929, Part II, 15 J. COMP. LEGIS. \& INT'L L. 3D SER. 112 (1933); Richard Rosendorff, The New German Company Act and the English Companies Act 1929, Part III, 15 J. COMP. LEGIS. \& INT'L L. 3D SER. 242 (1933). 
Corporate Law of 1937 (Aktiengesetz). ${ }^{119}$ The period from around 1916 up to 1945 is one of fundamental conceptual change in German corporate law thinking. In this period the liberal conception of corporate law is challenged and major legislative inroads are made. This is attributable to: the impact of the two World Wars on the relationship between private enterprise and the state; the political turmoil of early post World War I Germany, with the short lived socialist revolution and the need to accommodate the left in the political settlement of the Weimer Republic; the consequential rise of new corporatist and state socialist thinking about the relationship between business and society; the economic crises of 1924 and 1929 and their effect on German corporations; and the anti-capitalism and racism of the Nazi era.

An important figure in this process is Walther Rathenau. During his tenure as head of the War Raw Materials Department of the War Ministry (Kriegsrohstoffabteilung), Rathenau established the Kriegsrohstoffgesellschaften. ${ }^{120}$ These were private sector AGs placed under the control of the State that retained a power of veto. The principal owners were given State sureties to ensure their co-operation. Twenty-five such enterprises multiplied into around 200 specialized institutions and so-called War Committees (Kriegsausschusse) that by 1918 employed some 18,000 people. Such entities founded the development of German corporatism. However the experience of war capitalism was also one of apparent profiteering by private firms, leading to the establishment of the Reichstag's commission in 1916 , which found significant evidence of this practice. ${ }^{121}$

The experience of war capitalism led Rathenau to consider the future of industrial capitalist organization. Also significant were the ideas of "organized capitalism" associated with Hilferding, the state socialism of Plenge and the co-operative business ideas of von Moellendorf (Gemeinwirtschaft). ${ }^{122}$ However, it is in Rathenau's work Vom Aktienwesen,

\footnotetext{
119 Gesetz Uber AKTIengesellschaften Und Kommanditgesellschaften Auf AKTIEN (AKTIENGeSetZ) vom 30 Januar 1937

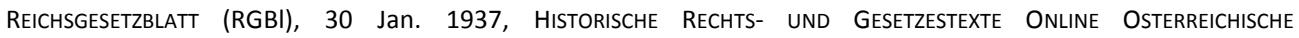
NATIONALBIBLIOTEK (Ger.), Teil 1 Nr. 15 s. 107, ALEX available at: http://alex.onb.ac.at/cgicontent/alex?aid=dra\&datum=1937\&page=213\&size $=45$ (last accessed: 1 February 2013).
}

\footnotetext{
120 See Hans-Ulrich Wehler, Deutsche Gesellschaftsgeschichte Band 4 1914-1949 (History of German Society, Volume 4, 3rd ed., 2008) at 47-52 on which this account draws. On the impact of this policy on Schering AG, see Christopher Kobrak, Politics, Corporate Governance and the Dynamics of German Managerial Innovation: Schering AG between the Wars, 3 ENTER. AND SOC'Y 429, 438 (2002).

${ }^{121}$ See WEHLER, supra note 120 , at 52-54, who feels that this led to a sharpening of distributional conflicts that fuelled the abortive socialist revolution at the end of the war.

${ }^{122} / d$. at 57.
} 
written in the last months of the War, that the essential nature of the reconsideration of the relationship between business and society of the time is captured. ${ }^{123}$

Rathenau saw two main problems with the existing system of corporate law: the overarching power of directors who were no longer controlled by the Aufsichtsrat, an organ that was in need of revitalization if it was to perform any useful role, and the ability of speculative shareholders to manipulate share prices in their favour and to the detriment of the corporation, who did not deserve the protection of their right to vote in the general meeting. ${ }^{124}$ He also saw the large modern business corporation as something that belonged to the wider business environment of the country and which worked in the wider social interest. Consequently, it could no longer be seen as a private law entity but one that required a new legal basis in public interest concerns. ${ }^{125}$ The enterprise should be recast in the context of a state socialist model which would allow it to realize its industrial and technical capacity and minimize the risk of speculative financial manipulation that could lead to its ruin. ${ }^{126}$

Rathenau's views met with a mixed reception when the reform of corporate law was considered after World War I. In legal circles they were largely dismissed, as the issue of protection of the small shareholder against large controlling interests continued to dominate lawyers concerns. ${ }^{127}$ Others took Rathenau's position and linked it to the critique of big enterprise capitalism, coming out of the US at the time, concerning the

\footnotetext{
${ }^{123}$ Walter Rathenau, Vom AkTienWesen: EINE Geschichtliche Betrachtung (1918).

${ }^{124}$ Id. at $13-33$.

125 According to Rathenau, "die Grossunternehmung ist heute uberhaupt nicht mehr lediglich ein Gebilde privatrechtlicher Interessen, sie ist vielmehr, sowohl einzeln wie in ihrer Gesamtzhal, ein nationaliwirschaftlicher, der Gesammtheit angehoriger Faktor, der zwar aus feiner herkunft, zu Recht oder zu Unrecht, noch die privatrechlichen Zuge des reinen Erwerbsunternehmens tragt, wahrend er langst und in steigendem Masse offentlichen Interessen dienseitbar geworden ist und hierdurch sich ein neues Dasainreacht geschoffen hat." RATHANEAU, supra note 123, at 38-39:
}

\footnotetext{
${ }^{126} I d$. at 41,62 . This approach has acquired the label "unternehmen an sich", given by Haussmann when he commented on Rathenau's famous rhetorical example of the risk that the Deutsche Bank could be overvalued and then forced into liquidation by the general meeting, saying that Rathenau had posited the need for the enterprise to secure the undertaking for itself against the majority of the general meeting: "Schutz des Unternehmens an sich gegenuber der Mehrheit in der Generalversammlung." See VON HEIN, supra note 76, at 140, citing FRITZ HAUSSMAN, VOM AKTIENWESEN UND AKTIENRECHT 14, 27 (1928).

${ }^{127}$ VON HEIN, supra note 76; Mann, supra note 111, at 226-227, who links Rathenau's ideas with the 1937 Law.
} 
division of ownership and control and the rising power of unaccountable management. ${ }^{128}$ However, the eventual changes in the law brought about under the Weimar Republic did not go very far beyond the traditional logic of corporate law.

The lengthy discussion process for reform was led by the Deutsche Juristentag (DJT) conferences of 1926 and 1928, and by a committee established by the Ministry of Justice. ${ }^{129}$ A Draft Law was presented to the legislature in 1931 but parts of it were enacted on 19 September 1931 by emergency order (NotVO) as a result of the pressure of the economic crisis and its effect on corporations. ${ }^{130}$ In particular, while the early post-war years saw a boom, the hyperinflation of 1924 and the crash of 1929 caused many corporate failures and materially affected the way in which German corporations organized their shareholdings and their accounts. Ways were devised to hide the true value of corporate assets from outsiders and many corporations, including joint stock banks, bought their own shares and so reduced their liable capital. ${ }^{131}$ A further concern was the threat of foreign acquisition of German businesses in the aftermath of the inflation crisis, which had made them attractive targets for foreign takeover. The corporate reaction was to issue shares with multiple voting rights (Mehrstimmrechtsaktien), owned by a syndicate controlled by management, or depot shares (Vorratsaktien), which were also loaded with multiple voting rights, and by the issue of preference shares with additional dividend payments (Vorzugsaktien). ${ }^{132}$ In either case, the impact on minority shareholders was detrimental as the value of their voting rights was undermined. ${ }^{133}$ This also increased the voting power of major banks that held proxy voting rights. ${ }^{134}$

\footnotetext{
${ }^{128}$ VON HEIN, supra note 76 , at $141-142$, citing Geiler. Ministry of Justice is documented therein, at 207-442.

${ }^{130}$ Rosendorff, Part I, supra note 118.

${ }^{131}$ See LEVY, supra note 7, at 168-169; FoHLIN, supra note 78, at 299.

${ }^{132}$ LEVY, supra note 7, at 169-170; Fohlin, supra note 101, at 262.

${ }^{133}$ LEVY, supra note 7; see further VON HEIN, supra note 76, at 149-157.

${ }^{134}$ Rosendorff, Part II, supra note 118, at 113.
}

${ }^{129}$ For a detailed analysis of the process and of the role played by US ideas, see id. at 126-169; see also Rosendorff, Part I, supra note 118, at 95. The DJT discussions of 1926 and 1928 are documented in QUELLEN FUR AKTIENRECHTSREFORM DER WEIMARER REPUblic 1926-31, vol. 1, 33-205 (Werner Schubert ed., 1999); the work of the 
The 1931 NotVO addressed such problems by ensuring greater transparency in accounting practices and in the information offered in the annual return, the balance sheet and the profit and loss account, and by requiring an examination of the books by independent auditors. $^{135}$ In this, the 1931 reforms follow the approach taken in the English Companies Act $1929 .^{136}$ It remained for the Law of 1937 to fully control the various types of multiple voting, depot and preference shares. ${ }^{137}$ In addition, the purchase of a company's own shares by a subsidiary was prohibited except in certain narrow cases. ${ }^{138}$ Minority rights were also strengthened. ${ }^{139}$ As regards the governance of corporations, the NotVO changed the role of the Aufsichtsrat in response to concerns that it had failed as a supervisory organ in preventing the collapse of so many corporations. ${ }^{140}$ During this period, the dual board system was scrutinized and compared with the Anglo-American unitary board system. However no shift to unitary boards was formally accepted. ${ }^{141}$ Instead, Art.VIII of the NotVO stipulated that the rules in the corporate statute regulating the composition and formation of the supervisory board and the remuneration of its members would terminate at the next general meeting, to be replaced by new rules voted by a simple majority; the period of service of all members of the board would also terminate and new members would be elected, provided their numbers did not exceed thirty and that no member could sit on the boards of more than twenty corporations.

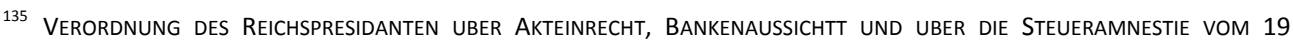
SEPTEMBER 1931 ReICHSGESETZBLATT, supra note 118, Arts. V and VI.

${ }^{136}$ Rosendorff, Part III, supra note 118, at 242-246.

${ }^{137}$ Fohlin, supra note 101, at 262-263. See GeSETZ UBER AKTIENGESELLSCHAFTEN UND KOMMANDITGESELLSCHAFTEN AUF AKTIEN (AKTIENGESETZ) VOM 30 JANUAR 1937 REICHSGESETZBLATT (RGBI), supra note 119, Arts. 159-168 on pre-emptive rights; Arts. 169-173, allowing special issue of shares without permission of stockholders for up to five years; Art. 174 , specific permission of stockholders and the Reich Ministry of Economics needed in specific cases of issues of convertible and participating bonds. Further, see Mann, supra note 111, at 235-237.

138 Verordnung des ReICHSPRESIDANTEN UBer AKTEINRECHT, BANKENAUSSICHTT UND UBER DIE STEUeRAMNESTIE VOM 19 SEPTEMBER 1931 ReICHSGESETZBLATT, supra note, 118 Art.1(1) new s. 227 HGB; see also, Rosendorff, Part III, supra note 118 at 248-249. This was carried through to the 1937 Law: see Mann, supra note 111, at 237-238.

139 Verordnung des Reichspresidanten UBer AKTEINRECHT, BANKENAUSSICHTT UND UBER DIE STEUERAMNESTIE VOM 19 SEPTEMBER 1931 ReICHSGESETZBLATT, supra note 118, at Art. VII new s.266(3) HGB.

${ }^{140}$ Rosendorff, Part II, supra note 118 , at 112.

${ }^{141}$ See VON HEIN, supra note 76, at 161-163; Rosendorff, Part I, supra note 118, at 98-100. 
This reform sought to decrease the perceived concentration of control in few hands of major corporations, a process that characterizes this period, ${ }^{142}$ though its impact was doubted at the time. ${ }^{143}$ It is notable that the NotVO did not have any developed rules on holding companies and relations with controlled undertakings. ${ }^{144}$ Such Konzernrecht would not fully emerge until the Aktiengesetz of $1965 .^{145}$ Finally, the NotVO did not challenge bank proxy voting, although the accompanying emergency measures on the supervision of banks did consider that the board of trustees should be empowered to lay down conditions on which banks could exercise proxy votes. ${ }^{146}$

The rise of Nazi power after 1933 had a major political impact on German corporate law. Although much continued from the 1931 reforms, and some of the wilder anti-capitalist ideas were pragmatically avoided to ensure business support (which also led to some privatizations of corporations that had been nationalized in the early 1930s in response to the Great Depression), the 1937 Law marked a shift towards state control over corporations. ${ }^{147}$ According to Kessler, the 1937 Law can be analyzed in four parts: firstly, it contains provisions encouraging the use of the corporate form for large businesses while discouraging the use of limited liability for small enterprises; ${ }^{148}$ secondly, it introduces

\footnotetext{
${ }^{142}$ On patterns of industrial concentration in this period, see Fohlin, supra note 101, at 229-230; WEHLER, sUpra note 120 , at $262-268$.

${ }^{143}$ Rosendorff, Part I, supra note 118.

${ }^{144}$ See Rosendorff, Part III, supra note 118 , at $250-253$, discussing the proposed rules of holding companies in the 1930 Draft Law that were not adopted in the NotVO; LEVY, supra note 7, at 172.

${ }^{145}$ See Fohlin, supra note 101 , at 267.

${ }^{146}$ Id. at 113

${ }^{147}$ See VON HEIN, supra note 76, at 172. See further, Kobrak, supra note 120. On Nazi privatisations, see Germa Bel, Against the Mainstream: Nazi Privatisation in 1930s Germany, 63(1) ECON. HIST. REV. 34 (1210). According to Overy, state ownership became much more widespread during the Second World War particularly in sectors related to armaments and strategic industries: Overy, supra note 111 , at 184 . For example, the Reichswerke, set up in 1937 by Hermann Goering, grew into a vast state holding company in iron ore mining, iron and steel, and armaments.
}

\footnotetext{
148 This includes a minimum capital on formation of 500,000 Reichsmarks (Art. 7); no shares issued without a minimum par value of at least 1000 Reichsmarks (Arts. 6 and 8); see Mann, supra note 111, at 227-228.
} 
greater publicity requirements to ensure greater transparency; ${ }^{149}$ thirdly, it is informed by the "Führerprinzip"; and, fourthly, it increases direct state control over the enterprise. ${ }^{150}$ The latter two aspects are Nazi innovations.

The "Führerprinzip" embodies the Nazi ideal of personal leadership in the interest of the Reich. Some experts argued that the US style unitary board was more suitable to the application of the Führerprinzip. However, the final advice to the government was that the German system remained better suited to this task. ${ }^{151}$ Although the term is not expressly used, by Art.70 (1) of the 1937 Law the management board (Vorstand) is made the central organ of the corporation and is tasked with the management of the corporation in the interests of the employees, the Volk and the Reich. ${ }^{152}$ The Führerprinzip is included in that, by Art.70 (2) the membership of the Vorstand can be composed of only one person. The members of the Vorstand remain to be appointed by the Aufsichtsrat for a term of five years under Art.75 (1). This leaves the two-tier board system in place, though the overall direction of the enterprise is now placed with the Vorstand, not, as in previous laws, with the Aufsichtsrat. The Vorstand continues to be supervised from the general meeting. ${ }^{153}$ Finally, direct State control is ensured by Art.288, which empowers the Reich Economic Court (Reichswirtschaftsgericht), on application of the Reich Ministry for Economics, to dissolve a corporation that is deemed to endanger the general welfare.

The effect of the 1937 Law on German corporate practices was rather less far reaching than its terms might suggest. Despite state controls over the issue of multiple voting shares, this issuing practice continued, especially in companies, such as I.G.Farben, whose multiple voting shares were never withdrawn by the state, thus effectively disenfranchising

\footnotetext{
149 This includes more information about corporate members (Arts. 100 and 128), more information for shareholders (Art. 112), and more details about group ownership structures as well as membership of cartels (Art.128 (8) and (9)); See Mann, supra note 111, at 231-233.

${ }^{150}$ See William Kessler, The German Corporation Law of 1937, 28(4) AM. Econ. ReV 653 (1938).

${ }^{151}$ VON HEIN, supra note 76 , at $179-181$.

${ }^{152}$ By Art. 70: “(1) Der vorstand hat unter eigener Verantwortung die Gesellschaft so zu leiten, wie dass Wohl des Betriebes und seiner Gefolgschaft und der gemeine Nutzen von Volk und Reich es forderen."

${ }^{153}$ For a detailed discussion, see Kessler, supra note 150, at 658-660; Mann, supra note 111, at 228-231; Detlev Vagts, Reforming the "Modern" Corporation: Perspectives from the German, 80 HARV. L. REV. 1 23, 41-43 (1966).
} 
non-controlling shareholders. ${ }^{154}$ Equally, controls over proxy voting by banks under Art.114 (4), which required banks to obtain express permission from shareholders to exercise proxy votes on their behalf, were ineffective in preventing this practice. ${ }^{155}$

The impact of the new relationship between the Vorstand and the Aufsichtsrat can be seen in the first corporate reorganization of note after the 1937 Law, that of Schering AG. Though formally the power of decision shifted to the Vorstand, its chair, Weltzien, retained only one vote under the new corporate bylaws. This was in line with the requirements of Art.70 (2) of the 1937 Law, which permitted a variation, under the bylaws, of the otherwise decisive power of the chairs vote in cases where the Vorstand was divided. This ensured that the chair of the Aufsichtsrat, Hans Berckemeyer, retained overall control as the principal decision-maker in the firm. ${ }^{156}$ Thus, the "Führerprinzip" could be side-stepped in practice and the control of the Aufsichtsrat protected. Intriguingly, one of the only cases in which Art.70 of the 1937 Law was ever used by the state to try to control the decisions of a company occurred in 1962, when a proposed price increase by Volkswagen was challenged unsuccessfully under Art.70 by the then Minister for Economics, Ludwig Erhart, on the grounds that this would damage German trade interests by making exports of a key export commodity too high. ${ }^{157}$

The main impact of the 1937 Law was to reduce the number of AGs and with it to reduce activity on the stock exchanges. From a total of ten thousand in 1933, the number of AGs fell to five thousand in $1939 .^{158}$ Equally, a further factor in the undermining of the AG was the Nazi reorganization of the stock exchanges in accordance with their anti-capitalist and anti-Semitic convictions. ${ }^{159}$ They replaced administrative personnel with Nazi supporters and passed laws to shift control over price setting to official brokers. They banned Jewish brokers from practice and forced Jewish shareholders to sell their stakes. Stock exchange

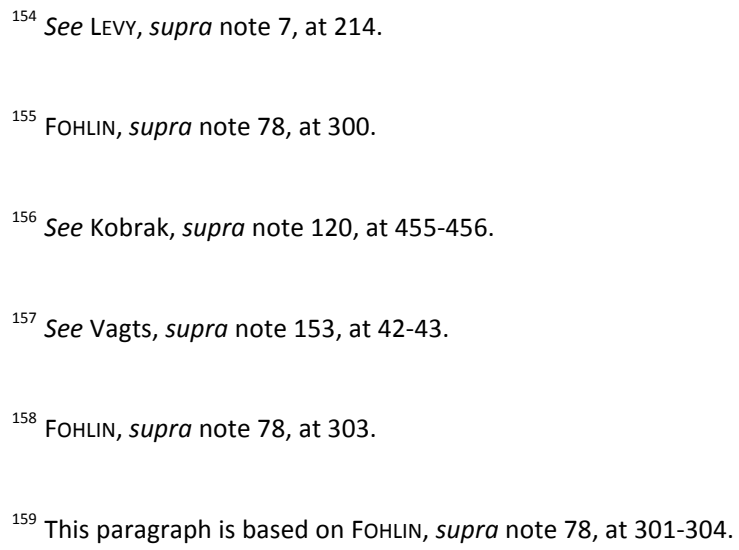


supervision was passed directly into the hands of central government, and limits were placed on dividends and on foreign currency dealings, which were banned completely in December 1938. During the Second World War the stock exchange was turned into a state monopoly. As the war progressed, the stock market became no more than a tool for increasing government expenditure. By the end of the war, although the Frankfurt and Berlin stock exchanges were still functioning (trade continued in Berlin until 18 April 1945), they were trading exclusively in Reich debt. The German stock market was just about dead as a source of corporate finance.

\section{E. The Reconstruction of German Corporate Law 1945-1990}

Although Germany was virtually destroyed at the end of the Second World War, German industry was relatively intact. ${ }^{160}$ However, the Allied occupying powers did not wish to see a revival of war potential in German industrial production. ${ }^{161}$ They were also concerned to ensure the introduction of a more open market economy. Thus, the principal thrust of Allied corporate policy was to de-concentrate the pre-war Konzerne through anti-cartel laws, targeting the chemical industry, iron and steel, and banks, and to privatize the network of state owned enterprises established during the 1930 s and $40 \mathrm{~s}^{162}$ In addition, the allied division of Germany is a significant factor in the post-War development of German corporate law. ${ }^{163}$ This resulted in West Germany retaining the 1937 Law while the German Democratic Republic (GDR) adopted the Soviet model of centrally planned industrial organization and administration. Thus, in the GDR, state owned combines, organized by periodic state plans, were the main characteristics of its industrial system. ${ }^{164}$

\footnotetext{
${ }^{160}$ Id. at 304 .

${ }^{161} / d$.

${ }^{162}$ Id.; see also Overy, supra note 111 , at 182,184 . But see the Volkswagen privatisation law which allowed the State of Lower Saxony to retain control over the new firm through controlling a fifth of all shares. This law was successfully challenged under EU law in 2007: see Peer Zumbansen \& Daniel Saam, The ECJ, Volkswagen and European Corporate Law: Reshaping the European Varieties of Capitalism, 8 GERM. L. J. 1026 (2007).

${ }^{163}$ See further, MARY FULBRoOK, A CONCISE HISTORY OF GeRMANY 204-212(2 ${ }^{\text {nd }}$ ed., 2004).

${ }^{164}$ Id., at 235-238. On the rise and fall of the centrally planned GDR economy, see HANS-ULRICH WEHLER, DEUTSCHE GESELLSCHAFTSGESCHICHTE BAND 5 1949-1990, 88-107 (History of German Society, Volume 5, 2008).
} 
In West Germany, the 1937 Law was in force until the reforms of 1965 . Why did it take so long to remove this "Nazi Relic"? Partly, this was because the 1937 Law offered workable corporate law rules. ${ }^{165}$ The Nazi aspects of the Law could simply be ignored in practice (even, as noted, in the Nazi period!) while the corporate formation, corporate governance and shareholder protection rules continued to be of use, given their largely pre-Nazi heritage. ${ }^{166}$ On the other hand, the post war reconstruction period in West Germany was one of great uncertainty. As Overy notes,

"[t]he defeat of the [Nazi] New Order, and the subsequent occupation, produced a prolonged argument about what was to be done with German industry. The restoration of a neo-liberal economy in the 1950s did not look at all certain in 1946." 167

The Allies' initial reluctance to restore German capitalism was abandoned and they encouraged considerable de-regulation. ${ }^{168}$ In addition, the new German political settlement enshrined private property and personal freedoms as constitutional values. ${ }^{169}$ This was supported by the theory of Ordoliberalism which lays the intellectual foundations of the post-war West German "Social Market Economy".

Ordoliberalism advocates for a middle ground between unregulated corporate capitalism and state directed corporatism. The regulatory power of the state is used to encourage the development of free markets, in particular through competition laws, but it accepts the public ownership of natural monopolies. This is coupled with safeguards for personal freedom and security. ${ }^{170}$ Worker co-determination and shareholder rights are seen as

\footnotetext{
${ }^{165}$ See Vagts, supra note 153, at 26, citing the Federal Governments draft proposal for new legislation of 1960, Entwurf Eines Aktiengesetzes mit Begrundung 93 (1960).

${ }^{166}$ See Vagts, supra note 153 , at 30-31.

167 Overy, supra note 111, at 189. For a detailed analysis of how West Germany returned to a liberal market economy, see NöRR, TEIL 1, supra note 11, Chs. 2 and 3.

${ }^{168}$ Overy, supra note 111, at 189; vON HEIN, supra note 76, at 193-194.
169 See Basic Law of the Federal Republic of Germany (Grundgesetz), 23 May 1949 Chapter One Basic Rights (Deutscher Bundestag, Official English Translation, 2010) available at: http://www.gesetze-im- internet.de/englisch_gg/index.html (last accessed: 1 February 2013).

\footnotetext{
${ }^{170}$ For an English summary of German Ordoliberal views from the period, see Carl Friedrich, The Political Thought of Neo-Liberalism, 49 AM. POL. SCI. REV. 509 (1965); Kurt Hanslowe, Neo-liberalism an Analysis and Proposed
} 
counterbalances to the managerial control of the corporation. The development of SMEs is encouraged. On the other hand, the existence of Konzernen is noted, and it is accepted that large enterprises play a socially useful role in the economy. Thus, they should be regulated not only by competition law but also through corporate law, to ensure a better balance between the need to manage the enterprise and to protect minority interests. It is out of these concerns that the model of post war German corporate law emerges. The main post war legislative developments involve the re-introduction of co-determination laws and the reform of the 1937 Aktiengesetz in 1965.

Apart from the dual board system, the other conventional characteristic of the German corporate model is the inclusion of worker representatives on the Aufsichtsrat, the codetermination system (Mitbestimmung). This aspect of German corporate governance and law does not have its legal roots in the $19^{\text {th }}$ but in the early $20^{\text {th }}$ century. ${ }^{171}$ Though the idea of worker participation in corporate governance was already being debated in the $19^{\text {th }}$ century, ${ }^{172}$ it was not until the 1920 s that a system of worker participation was first introduced by law. This was a response to the development of the revolutionary council movement in the early years after World War I. Workers would establish such bodies in their enterprises as a means of developing co-operative decision-making procedures with management. ${ }^{173}$ The Works Councils Law (Betriebsrätegesetz) of 1920 required the formation of works councils with parity representation of blue- and white-collar employees in all establishments with over 20 employees. ${ }^{174}$ The supplementary amendment of 1922

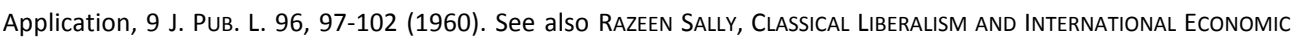
ORDER (1998), Chapter 6, "Ordoliberalism and the Social Market." For a recent examination, see Ralf Ptak, Neoliberalism in Germany: Revisiting the Ordoliberal Foundations of the Social Market Economy, in THE ROAD FROM Mont Pelerin: The Making of the Neoliberal Thought Collective 98 (Philip Mirowski \& Dieter Plehwe eds., 2009). In German, see NÖRR, TEIL 1, supra note 11, Chapter 4. The main organ of the ordoliberal movement is the journal Ordo: Jahrbuch fur die Ordnung von Wirtschaft und Gesellschaft (Yearbook of Business \& Society), available online at: http://www.ordo-jahrbuch.de/en/available-volumes.html (last accessed: 1 February 2013).

\footnotetext{
171 DIGNAM \& GALANIS, supra note 1 , at 264 , incorrectly assert that "By 1884 corporate law reform led to the supervisory board being introduced with employee representation on it..."

172 See Du PLESSIS ET AL., supra note 10, at 154-155; Gregory Jackson, Contested Boundaries: Ambiguity and Creativity in the Evolution of German Codetermination 13 (RIETI Discussion Paper Series No. 04-E-022, 2004), available at: http://papers.ssrn.com/sol3/papers.cfm?abstract id=569541 (last accessed: 1 February 2013); DONNELLY ET. AL., supra note 111 , at 18-21, discussing early forms of worker participation in the $19^{\text {th }}$ century German coal industry and in war industries during World War I.

${ }^{173}$ DonNeLLY ET. AL., supra note 111, at 21. On the impact of this policy on Schering AG, see Kobrak, supra note 120 , at 483 .

${ }^{174}$ Reichsgesetzblatt (RGBI) 1920 I s.147; see also Jackson, supra note 172.
} 
applied to all types of companies, not only to public limited companies. In companies where the board consisted of more than three members two supervisory board seats were reserved for works council members and in all other cases one seat was reserved for works council members. $^{175}$

The Weimar era co-determination laws were effectively abolished by the Nazis. Codetermination laws were re-introduced, first in the iron and steel industry in 1951 (Montanmitbestimmung) and, more generally, in 1952 (Betriebsverfassungsgesetz) and then revised in 1976. ${ }^{176}$ The Co-Determination Act 1976 (Mitbestimmungsgesetz) stipulates that, for any AG, KGaA, GmbH or Genossenschaft with over 2000 employees, 50\% of the seats on the supervisory board will be allocated to employee representatives. ${ }^{177}$ The conventional explanation for this system is that it was introduced by the British occupation authorities in conjunction with German trade unionists, in order to ensure class parity in German enterprises with the aim of preventing any resurgence of the dictatorial tendencies of the Third Reich. ${ }^{178}$ However, as noted above, the concept of worker participation enterprises has been present in German legal thought since at least the early 1920 s, if not earlier, and so can be seen as a restoration of certain themes from this historical discourse into the social market economy of the post-war years.

The main impact of co-determination on corporate law has been to entrench the two-tier board structure in undertakings that qualify for the provision of labour representatives by reason of their size. Thus, in 1980, a commission of the Federal Ministry of Justice on the reform of the law of business associations expressly ruled out the adoption of a unitary

\footnotetext{
175 Gesetz uber die EntSendung von Betriebsratmitgliedern in den AufsichtSRAt vom 15 Februar 1922, 15 Feb. 1992, ReIChSGESETZBLATt (RGBL) 1922 I No. 17 pp. 209/10 (Ger.). See Du Plessis ET AL., supra note 10, at 154. Levy feels these laws were ineffective: see LEVY, supra note 7, at 172.
}

\footnotetext{
${ }^{176}$ See DONNELLY ET AL., supra note 111, at 22-23; Vagts, supra note 153, at 64-89; vON HeIN, supra note 76, at 219224; NÖRR, TEIL 1, supra note 11, at Chapter 6. For the leading historical treatise on co-determination, see HANS Teutenberg, Geschichte der Industriellen Mitbestimmung in Deutschland (History of Industrial Co-Determination in Germany, 1961).

177 Mitbestimmungsgesetz vom 4. MAI 1976, 4 May 1976, BGBL. I S. 1153, Arts. 1, 7; German version available at: http://bundesrecht.juris.de/bundesrecht/mitbestg/gesamt.pdf (last accessed: 1 February 2013). For analysis of the background to the 1976 reforms, see Heinz Hartmann, Codetermination Today and Tomorrow, 13(1) BRIT. J. IND. REL. 54 (1975); NÖRR, TEIL 2, supra note 11, at Chapter 6.

${ }^{178}$ DU PLESSIS ET AL., supra note 10, at 155. See also Herbert Spero, Co-Determination in Germany, 48 AM. POL. SCI. REV. 1114 (1954).
} 
board system for Germany as a direct result of the legal implications for the codetermination process. $^{179}$

The main aim of the reform of the Aktiengesetz in 1965 was to restore the efficient operation of a stock market and to encourage corporate finance through the issue of tradable shares, and to discourage the financing of business through re-investment of own capital. ${ }^{180}$ Thereby, the allocative efficiency of capital markets could be restored. ${ }^{181}$ Other aims included improving the lot of small shareholders, restoring the supremacy of the Aufsichtsrat over the Vorstand, and to regulate the affairs of large corporate groups, so as to promote their business utility while balancing this against the protection of minority shareholders. The resulting major innovation was the development of comprehensive corporate group regulation which was internationally unprecedented at the time. ${ }^{182}$ In addition, the 1965 Law once again tackled the issue of proxy voting by banks. As with previous laws, banks were obliged to obtain written authorization to cast such votes. This authorization would be valid for up to fifteen months and could be given for all or part of the customer shareholder's portfolio. The bank had to give the customer the opportunity to direct how the vote would be cast, and to inform how the bank intended to vote. In the absence of instructions the bank could vote as it wished. ${ }^{183}$

179 UNTERNEHMENSRECHTSKOMMISSION 177 (Corporate Law Commission, 1980), cited by von HIEN, supra note 76, at 224.

180 AkTIengeSetz vom 6 September 1965, 6 Sep. 1965, BGBI I, s. 1089, available at: http://www.gesetze-iminternet.de/bundesrecht/aktg/gesamt.pdf (Ger.)(last accessed: 1 February 2013). For comparative analysis, see ANDENAS \& WOOLDRIDGE, supra note 10. For a recent account of the current law, see TIM DRYGALA, MARKO STAAKE \& StEPHAN SZALAI, KAPITALGESELLSCHAFTRECHT (2012). See also Vagts, supra note 153, at 27; and, for a detailed analysis of the debates leading to the 1965 Law, see Nörr, TEIL 1, supra note 11, at 201-214 and Chapter 9. See also HEINZ-

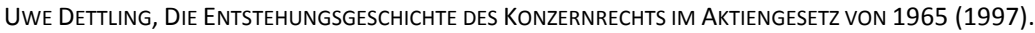

${ }^{181}$ VON HEIN, supra note 76, at 195-196.

182 See AKTIENGeSetZ Vom 6 SePtember 1965, supra note 180, Arts. 17-18, 291-323; see NöRR, TEIL 1, supra note 11, at 253-256. In 1985, these rules were extended by the Federal Supreme Court to GmbH based groups in the Autokran judgment: see NÖRR, TEIL 2, supra note 11, at 257-258. For a more recent analysis, see Rene Reich-Graefe, Changing Paradigms: The Liability of Corporate Groups in Germany, 37 CoNN. L. R. 785 (2005).

${ }^{183}$ See AKTIENGeSetz Vom 6 SePtemBer 1965, supra note 180, Arts. 128, 135. 
The reforms of 1965 did not challenge the post-war concentration of German industry or the power of the banks. ${ }^{184}$ This was the result of a decline in household shareholding and continued concentration in the hands of family owners and inter-firm block holdings. ${ }^{185}$ The corporate group laws merely regulated the losses to minority shareholders arising out of decisions taken in the interests of the group as a whole. ${ }^{186}$ The block holding of shares continued until the reforms of the 1990s. ${ }^{187}$ Equally, the rules on proxy voting could not stop the banks from wielding their power as most customers would not direct how they should vote. ${ }^{188}$ This led to further reforms in the 1990s. ${ }^{189}$

The final part of the post-war reconstruction of corporate law involves the reunification of Germany in 1990. By Art.8 of the Unification Treaty of 31 August, West German law entered force on the territory of the former GDR and so West German corporate law became the governing law for all Germany. ${ }^{190}$ This meant that economic entities of the GDR would have to change from state to private ownership. Given that there had been no privately owned enterprises in the GDR since 1972, economic entities would be unable to come within the provisions of existing corporate law. ${ }^{191}$ Accordingly, their assets were

\footnotetext{
${ }^{184}$ For evidence of levels of concentration and bank control in late 20th century Germany, see Jeremy Edwards \& Markus Nibbler, Corporate Governance: Banks Versus Concentration in Germany, 15 ECONOMIC PoLICY No. 31 (2000), available at: http://papers.ssrn.com/sol3/papers.cfm?abstract_id=247410 (last accessed: 1 February 2013); Ekkehart Boehmer, Who Controls German Corporations?, in CORPORATE GOVERNANCE REGIMES: CONVERGENCE AND DIVERSITY 268 (Joseph McCahery, Piet Moerland, Theo Raaijmakers \& Luc Renneboog eds., 2002); see also Fohlin, supra note 101, at 231-237.

${ }^{185}$ See Fohlin, supra note 101, at 231-237.

${ }^{186}$ Further, see Muchlinski, supra note 104, at 329-330.

${ }^{187}$ VON HEIN, supra note 76 , at 196.

${ }^{188}$ See FoHuIN, supra note 78 , at 314.

${ }^{189}$ On which, see von HEIN, supra note 76, at 218-248; Fohlin, supra note 101, at 267-268.

190 Unification Treaty, August 31, 1990, Aug. 31, 1990, GB1. (GDR) I, s. 1629; BGB1. (FRG) II, s. 889, available at: http://germanhistorydocs.ghi-dc.org/pdf/eng/Unification_Treaty.pdf (last accessed: 1 February 2013).

${ }^{191}$ See further Johannes Wasmuth, The Reunification Treaty between the Federal Republic of Germany and the German Democratic Republic and its effects on commercial, company and bankruptcy law, 1991 INT'L BUS. L. J. 765
} 
transferred to the Treuhand, the public legal entity which, by Art.25 of the Unification Treaty, "shall continue to be charged, in accordance with the provisions of the Trusteeship Act [Treuhandgesetz], with restructuring and privatizing the former publicly owned enterprises to bring them into line with the requirements of a competitive economy." 192 By Art.11 of the Treuhand Law, all former GDR enterprises were converted into capital stock corporations (Kapitalgesellschaften) and remained under the control of the Treuhandanstalt, the body established under Art.2 of the Treuhand Law, to undertake the privatization process. The enterprises that were not yet privatized would be regulated according to the rules set out in Arts.16 to 23 of this law. ${ }^{193}$

\section{F. Concluding Remarks: Globalization, Comparison and German Corporate Law}

Since 1990, German corporate law has undergone a series of reforms aimed at creating a more shareholder oriented system of corporate law. In particular, laws on control and transparency of corporations and on registration and facilitation of voting rights sought to offer more information to shareholders and to revisit the need to regulate proxy voting. Banks must now separate their voting plan division form the rest of the bank and must offer greater disclosure as to their voting intentions. ${ }^{194}$ This coincides with the gradual withdrawal of banks as shareholders in non-financial corporations. ${ }^{195}$ In addition, in 2002, the Government Commission appointed by Justice Minister in September 2001 adopted the German Corporate Governance Code, which forms the basis of current corporate

(1991), who lists the following types of entities: "volkseigene Kombinate" (peoples' combines), "Kombinatsbetriebe"(combine enterprises) and "volkseigene Betriebe" (peoples' enterprises).

192 Treuhandgesetz vom 17 JUNI 1990 (Trust Law), 17 June 1990, GBI. (GDR) I, s. 300, available at: http://www.gesetze-im-internet.de/bundesrecht/treuhg/gesamt.pdf (Ger.)(last accessed: 1 February 2013). The handling of privatization by the Treuhand has been controversial: see Wendy Carlin, Privatization in East Germany, 1990-92, 10(3) GERM. HIST. 335 (1992); Joerg Roesler, Privatisation Alone Cannot Solve East Germany's Economic Problems: Reflections on Wendy Carlin's Article 'Privatisation in East Germany 1990-92', 12(1) GERM. HIST. 64 (1994); Wendy Carlin, Wages, Privatization and Industrial Collapse: A Reply to Jorg Roesler's reply 'Privatization alone cannot solve east Germany's economic problems' (German History 12/1 (1994)), 12(2) GERM. HIST. 190 (1994).

\footnotetext{
${ }^{193}$ For the legal forms of enterprises in transformation, see Michael Gruson \& Georg F. Thoma, Investments In The Territory Of The Former German Democratic Republic, 14(3) FORDHAM INT'L L. J. 540, 545-552 (1990).

${ }^{194}$ Fohlin, supra note 101, at 267.

195 See DIGNAM \& GALANIS, supra note 1 , at 362-371.
} 
disclosure law. ${ }^{196}$ Equally, the impact of EU law has resulted in new rules on corporate residence in light of the Centos Case in the European Court of Justice, allowing German corporations to incorporate outside Germany without loss of their legal rights, and the introduction of a new supranational corporate form the Societas Europea (SE) which has been taken up by German corporations as a vehicle for European expansion. ${ }^{197}$

Furthermore, the takeover in 2000 of Mannesmann by Vodafone gave credence to the idea that a market for corporate control was finally emerging in Germany. ${ }^{198}$ Moreover, the system of co-determination is being challenged as a brake on enhancement of shareholder value, though it remains a significant feature of the German industrial landscape. ${ }^{199}$ These changes can all be seen as a reply to the challenge of globalization.

Whether this represents evidence of convergence between German corporate law and the shareholder oriented Anglo-American system remains open to debate. ${ }^{200}$ The larger question is whether such an issue is any longer relevant. A new wave of corporate governance history has emerged, on whose methodology the paper relies, which is more firmly rooted in archival research, and is skeptical of arguments based on path dependency and the neo-liberal tendency to value market-based relationships over co-ordinated

\footnotetext{
${ }^{196}$ This is achieved through the declaration of conformity pursuant to Article 161 of the AKTIENGESETZ 1965, as amended by Art.1 (16) of the TRANSPARENCY AND DISCLOSURE LAW, 19 July 2002, BGBI 2002 I, Nr. 50 s. 2681, available at: http://www.bgbl.de/Xaver/start.xav?startbk=Bundesanzeiger_BGBI (last accessed: 1 February 2013), which entered into force on 26 July 2002. See The German Corporate GovernANCE Code, as amended on 15 May 2012, available at: http://www.corporate-governancecode.de/eng/download/kodex_2012/D_CorGov final May 2012.pdf (last accessed: 1 February 2013). See also DIGNAM \& GALANIS, supra note 1 , at 342-343.

${ }^{197}$ Case C-212/97, Centros Ltd v. Erhvervs-OG Selskabsstyrelsen, 19992 C.M.L.R. 551; see also DIGNAM \& GaLANIS, supa note 1 , at 315-319.

${ }^{198}$ Martin Höpner \& Gregory Jackson An Emerging Market for Corporate Control? The Mannesmann Takeover and German Corporate Governance, Discussion Paper 01/4 (2001), available at: http://www.mpi-fgkoeln.mpg.de/pu/mpifg_dp/dp01-4.pdf (last accessed: 1 February 2013); DIGNAM \& GALANIS, supra note 1, at 371378.

${ }^{199}$ See DIGNAM \& GALANIS, supra note 1, at 319-322; Jackson, supra note 172.

${ }^{200}$ For the extensive discussion by Dignam and Galanis, who see a degree of convergence but also consider that the insider model of German law has on the whole endured and could resurface as a superior response to the impact of global economic crisis, see DIGNAM \& GALANIS, supra note 1, at 409-419.
} 
arrangements. $^{201}$ Rather, it seeks to go beyond the 'insider/outsider' dichotomy and to show that corporate law and governance systems do not fall neatly into either category, either over time or at any particular time, and that hybrid characteristics of each system can co-exist at any one time in any system, and that the limited liability joint stock corporation is not the only solution to the problem of enterprise governance that has historically allowed for a wider range of solutions. ${ }^{202}$ In this light, a number of lessons arise out of this historical excursus which should inform legal debate over the nature of German corporate law.

The first is that German corporate law developed during the $19^{\text {th }}$ century along more or less similar lines to the other European origin systems based on the need for capital and under the influence of economic liberalism. Comparative legal thought was highly influential in this process. Thus, the German system in the $19^{\text {th }}$ century can be seen not as an alternative to, but as a variant of, a common core of corporate law principles, originating in the French Code de Commerce and in English law, which played a formative role in German legal thought. Unsurprisingly, quite similar basic elements of corporate law emerged in earlier German laws, and in the reforms of 1870 and 1884, as in England and France at the time. The key result of the reforms of 1870 and 1884 was the replacement of the concession system by freedom of incorporation through registration, albeit with more demanding minimum capital and transparency requirements.

Second, the dual board system appears overemphasized as a significant differentiating factor. It was introduced as a mandatory requirement in the 1870 reforms, and reinforced in 1884 , due to a compromise between the Hanseatic Cities' desire for complete corporate freedom and Prussian concern over loss of state control over corporations, and not as a result of some inherent quality in German corporate law. After all, the Prussian law of 1843 had a unitary board under the concession system. In addition, the alleged causal relationship between the introduction of the dual board system and the extension of bank dominance over German industry must be treated with caution. As noted in section 2, the role of the banks as a controlling influence over corporate policy and increasing concentration is at least open to historical doubt. Nor is it clear that the banks wanted this. Indeed, Georg Siemens, the head of the management board of Deutsche Bank (a leading example in the bank domination thesis) in the 1870s, expressed dissatisfaction with the dual board structure. ${ }^{203}$ Furthermore, the ability of the Aufsichtsrat to control dominant

\footnotetext{
${ }^{201}$ See the papers by Herrigel, supra note 9, the special issue of Enterprise and Society (Vol.8(3), 2007), and - on Germany - the work of Fohlin cited in the paper.

${ }^{202}$ See Herrigel, supra note 9, at 481-482.

${ }^{203}$ See Franks et. al., supra note 57, at 4 note 3, citing the criticism of the supervisory board by Georg Siemens.
} 
managers has been repeatedly doubted in Germany, especially after economic crashes and scandals. In practice, the German corporation, as much as the US or English corporation, has become subject to the centralized control of key managers and the agency problem is similar. A further element is the adoption of the $\mathrm{GmbH}$, which envisages a unitary board structure. It is not until the advent of the post World War II system of co-determination that the larger $\mathrm{GmbHs}$ had to adopt the dual board system to accommodate worker representatives. Many $\mathrm{GmbHs}$ remain unitary board firms. Given their numerical importance in German corporate history this should not be overlooked in future comparative corporate law study.

Third, the issue of shareholder protection was addressed in the $19^{\text {th }}$ century more comprehensively than in other capitalist economies of the period. Despite continuing debates on the issue, the German Kaiserreich of the 1870 s and 1880s can be seen, in this respect, as well as through its espousal of freedom of incorporation, as a facilitative state which helped to develop German securities markets, not as an anti-liberal interventionist state, despite its dominance by conservative Prussian landed interests. ${ }^{204}$ Concern for the small shareholder continued into the Weimar Republic when new standards of corporate disclosure were introduced in 1931. The gradual destruction of the stock market by Nazi intervention, which in effect denied post-war Germany access to a domestic securities market for its reconstruction and led to the rise of concentrated block-holdings, is a more likely cause of the apparent loss of strong shareholder protection in German law. Even then the 1937 law retained many protections put in place by the 1931 reforms and added further ones, especially against multiple voting shares and proxy voting.

After World War II, a major policy aim was to rectify the shareholder protection problem. That reform was not really successful until the 1990s. This reflects the inability of the political order to affect the entrenchment of post-war block-holding managerial interests until the onset of globalization and the reorientation of German business strategies. It is also a result of shifting ideas within the German legal profession, which increasingly advocates a liberal shareholder oriented model of the corporation and is a driver of reform. ${ }^{205}$ Furthermore, reforms in German accounting practice, related in part to the

\footnotetext{
${ }^{204}$ On which, see Fulbrook, supra note 163 , at $137-144$, who believes that the state was intervening in industry but does not document the point. The more convincing position is given by VON HEIN, supra note 76 as discussed in supra note 111, Mann, supra note 111, and Overy, supra note 111.

${ }^{205}$ See Philipp Klages, The contractual turn: How legal experts shaped corporate governance reforms in Germany, 1 Socio-ECONOMic ReVIeW AdVAnCe AcCess (2012).
} 
adoption of International Accounting Standards for all publicly listed corporations under the European IAS Regulation EC No.1606/2002, have assisted in this process. ${ }^{206}$

Finally, co-determination, in its current form a product of recent times, has a stronger claim to be the truly distinctive feature of the German system. This institution, and the political compromise that it represents, is keeping the German corporate structure in place, rather than any 'legal family' factor. It is certainly not a civil law issue, as codetermination could be adopted in a common law jurisdiction. Nor is it fair to call this national political compromise an 'insider' response: it is too much a part of the present German social order to be seen as a type of corporate interest. It is not really even corporate law (any functional comparison would render it apiece with labour law in AngloAmerican thought) but a public law based system of control over class conflict that affects corporate governance. Should co-determination fall, the consequences for the development of German corporate law would be far reaching, possibly even ending the dual board system?

\footnotetext{
${ }^{206}$ See Eva Heidhues \& Chris Patel, A critique of Gray's framework on accounting values using Germany as a case study, 22 CRITICAL PeRSPECTIVES ON ACCOUNTING 273, 281 (2011).
} 